\title{
Meningkatkan Kemampuan Pemecahan Masalah pada Pelajaran Matematika Melalui Strategi Pembelajaran Peningkatan Kemampuan Berfikir pada Siswa Kelas IV Madrasah Ibtidaiyah Al Wathaniyah Tualang Kecamatan Tualang Kabupaten Siak
}

\author{
Hidayatul Alawiyah ${ }^{1}$, Melly Andriani ${ }^{2}$ \\ ${ }^{1,2}$ Program Magister Pendidikan Madrasah Ibtidaiyah, Universitas Islam Negeri Sultan \\ Syarief Kasim Riau \\ e-mail: Rafikaelsaoktaviani@gmail.com
}

\begin{abstract}
ABSTRAK. This research aimed at increasing student problem-solving ability on Mathematics subject through Thinking Skill Enhancementlearning strategy at the fourth grade of Islamic Elementary School of Al WathaniyahTualang, Tualang District, Siak Regency. This research was instigated by the low of student problem-solving ability, it could be seen from 3 of 20 students or $15 \%$ showing problem-solving ability that was on good category because many students were not yet able to understand the problems, tocarry out calculations, and to do planning to complete and recheckcalculation results properly. It was a Classroom Action Research. The subjects of this research were a teacher and 20 students atIslamic Elementary School of Al WathaniyahTualang, Tualang District, Siak Regency. Observation, test, and documentation were the techniques of collecting the data. Analyzing the data was done by using qualitative descriptive analysis with percentage. Based on the research finding and data analysis, it showed problemsolving ability that 3 students or $15 \%$ were on good category before the action. After implementing Thinking Skill Enhancementlearning strategy in the first cycle, student problem-solving ability increased, 14 students or $70 \%$ were on good category. In the second cycle, student problem-solving ability increased, 20 students or $100 \%$ were on good category. It meant that it had achieved the successful indicator that was determined. Therefore, it could be concluded that the implementation of Thinking Skill Enhancementlearning strategy could increase student problem-solving ability on Mathematics subjectat the fourth grade of Islamic Elementary School of Al WathaniyahTualang, Tualang District, Siak Regency.
\end{abstract}

Kata kunci: Problem-Solving Ability, Thinking Skill EnhancementLearning Strategy 


\section{PENDAHULUAN}

Pelajaran Matematika merupakan wadah yang dapat digunakan untuk meningkatkan kemampuan dan keterampilan intelektual. Matematika biasanya dianggap sebagai pelajaran yang sulit oleh anak-anak maupun orang dewasa. Meskipun dianggap sulit namun matematika merupakan ilmu dasar dalam kehidupan manusia yang memiliki peran penting. Dalam pendidikan, matematika merupakan bidang studi yang dipelajari oleh semua siswa mulai dari sekolah dasar sampai sekolah menengah tingkat atas.

Matematika yang diajarkan di sekolah memiliki peran penting dalam mendukung tercapainya tujuan pendidikan nasional. Secara umum tujuan pembelajaran matematika di sekolah dapat digolongkan menjadi: 1) Tujuan yang bersifat formal, menekan kepada menata penalaran dan membentuk kepribadian siswa. 2) Tujuan yang bersifat material, menekankan kepada kemampuan memecahkan masalah dan menerapkan matematika (Melly dan Mimi, 2013: 13).

Berdasarkan tujuan pembelajaran matematika di sekolah yang telah dijelaskan, kemampuan yang harus dimiliki siswa dalam pembelajaran matematika diantaranya adalah kemampuan pemecahan masalah.Kemampuan pemecahan masalah merupakan kompetensi strategik yang diajukan untuk siswa dalam memahami, memilih pendekatan dan strategi pemecahan dan menyelesaikan model untuk menyelesaikan masalah. Kegiatan belajar yang bertujuan untuk meningkatkan kemampuan pemecahan masalah matematika membuat siswa dapat mengembangkan kemampuan dalam berpikir.

Pemecahan masalah termasuk aktivitas kognitif tingkat tinggi yang bermanfaat bagi siswa untuk dapat membandingkan atau membedakan sesuatu, merumuskan dan menyelesaikan suatu permasalahan, dapat mengeluarkan ide-ide, serta mampu membuat keputusan dalam suatu masalah (Zulfah : 1). Hal ini sesuai dengan pendapat Leeuw yang dikutip oleh Sudjimat yang menyatakan bahwa belajar pemecahan masalah pada hakekatnya adalah belajar berpikir (learning to think) atau belajar bernalar (learning to reason), yaitu berpikir atau bernalar mengaplikasikan pengetahuan-pengetahuan yang telah diperoleh sebelumnya untuk memecahkan masalah-masalah baru yang belum pernah dijumpai (Sudjimat, 1995 : 28).

Proses pembelajaran yang mengkondisikan siswa untuk memecahkan masalah selain dapat meningkatkan keterampilan intelektual, kemampuan tersebut juga dapat digunakan siswa ketika menghadapi masalah dalam kehidupan sehari-hari. Mengajarkan penyelesaian masalah kepada siswa, memungkinkan siswa itu lebih analitik dalam mengambil keputusan dalam hidupnya. Setiap orang pasti dan akan selalu dihadapkan dengan suatu masalah, oleh karena itu dalam kegiatan pembelajaran guru juga diharapkan selalu membiasakan siswa untuk melakukan kegiatan yang bertujuan untuk memecahkan masalah. Gagne yang dikutip Muhammad Yaumi berpendapat bahwa, "The central point of education is to teach people to think, to use theirrational power, to become better problem solver. Disini, penyelesai masalah (problem solver) yaitu siswa merupakan tujuan dalam pelaksanaan pendidikan. Pendidikan seharusnya dapat menciptakan siswa-siswa 
yang memiliki kemampuan berpikir rasional dan mampu menggunakan daya nalar dalam menghadapi kehidupan. Integrasi penyelesaian masalah dalam pembelajaran merupakan solusi cerdik dalam mengembangkan kecerdasan dan kemampuan peserta didik." (Muhammad Yaumi, $2012: 82$ )

Kurikulum matematika sekolah yang memiliki tujuan agar siswa mampu menghadapi perubahan-perubahan ilmu pengetahuan dan teknologi yang berkembang semakin pesat, mengharuskan guru untuk memberikan pembekalan yang maksimal terhadap siswa, dalam pelaksanaannya di sekolah pembekalan tidaklah cukup hanya dengan kegiatan pembelajaran yang bersifat hapalan, latihan pengerjaan soal yang rutin, serta proses pembelajaran biasa. Oleh sebab itu wajarlah jika pemecahan masalah matematis merupakan bagian yang sangat penting, bahkan paling penting dalam belajar matematika. Siswa diharuskan mempunyai kemampuan dan keterampilan dalam memecahkan masalah yang berhubungan dengan soal-soal matematika, sebagai sarana baginya untuk mengasah penalaran yang cermat, logis, kritis, analitis, dan kreatif (Djamilah, 2019).

Pemecahan masalah matematika sering kita jumpai dalam bentuk soal cerita dalam kehidupan sehari-hari. Ini menjadikan matematika dapat dilihat secara realistis. Akan tetapi kenyataannya dari hasil observasi, siswa justru sulit memecahkan masalah matematika dalam bentuk soal cerita. Mereka sulit dalam mengidentifikasi masalah, memahami makna dari bahasa soal, mengambil keputusan dan sulit mengubah soal cerita kedalam model matematika.

Berdasarkan observasi awal yang peneliti lakukan pada siswa kelas IV Madrasah Ibtidaiyah Al Wathaniyah Desa Tualang, diperoleh data bahwa siswa belum mencapai Kriteria Ketuntasan Minimal (KKM) yang telah ditetapkan yaitu 70. Dari hasil observasi awal 20 siswa dikelas, yang tuntas hanya 3 orang $(15 \%)$. Dapat disimpulkan bahwa hampir 85\% siswa masih sulit dalam memecahkan masalah soal matematika materi KPK dan FPB. Hal ini tampak jelas jika dilihat dari hasil soal tes siswa tersebut. Kebanyakan dari mereka tidak mampu mengubah soal pemecahan masalah matematika kedalam model matematika, misalnya jawabannya tidak sesuai dengan yang dinyatakan dalam soal, salah menafsirkan apa yang diketahui, tidak tepat dalam pemilihan dan penggunaan rumus, bahkan ada yang hanya menuliskan jawaban akhir tanpa mengidentifikasi hal yang diketahui, ditanya dan proses penyelesaiannya.

Rendahnya kemampuan pemecahan masalah siswa tersebut dapat terlihat dari beberapa gejala-gejala diantaranya sebagai berikut: (1) Dari 20 jumlah siswa, hanya 3 orang atau $15 \%$ siswa yang bisa memahami dan menyelesaikan masalah yang diberikan oleh guru dengan baik. (2) Dari 20 jumlah siswa, hanya 2 orang atau 10\% siswa yang dapat merencanakan penyelesaian masalah dengan baik, sedangkan 18 orang atau 90\% masih belum tepat. (3) Dari 20 jumlah siswa, hanya 3 orang atau 15\% siswa yang tepat menyelesaikan langkah-langkah pemecahan masalah, sedangkan 17 orang atau 85\% orang masih belum tepat. (4) Dari 20 jumlah siswa, hanya 2 orang atau 10\% siswa yang bisa 
memeriksa kembali hasil perhitungan yang telah mereka kerjakan, sedangkan 18 orang atau $90 \%$ masih belum tepat.

Berdasarkan latar belakang di atas, maka peneliti tertarik melakukan suatu Penelitian Tindakan Kelas sebagai upaya dalam melakukan perbaikan terhadap proses pembelajaran Matematika dan peningkatan kemampuan pemecahan masalah siswa dengan judul: Meningkatkan Kemampuan Pemecahan Masalah pada Pelajaran Matematika Melalui Strategi Pembelajaran Peningkatan Kemampuan Berfikir pada Siswa Kelas IV Madrasah Ibtidaiyah Al Wathaniyah Tualang Kecamatan Tualang Kabupaten Siak.

Tujuan dari penelitian ini adalah untuk mendeskripsikan penerapan Strategi Pembelajaran Peningkatan Kemampuan Berfikir dalam meningkatkan Kemampuan Pemecahan Masalah pada Pelajaran Matematika di Kelas IV Madrasah Ibtidaiyah Al Wathaniyah Tualang Kecamatan Tualang Kabupaten Siak.

\section{METODOLOGI}

Penelitian ini adalah penelitian tindakan kelas. Penelitian dilaksanakan di kelas IV Madrasah Ibtidaiyah Al Wathaniyah Tualang Kecamatan Tualang Kabupaten Siak. Adapun waktu penelitian pada bulan Januari tahun ajaran 2019-2020. Subjek dalam penelitian ini adalah siswa kelas IV dengan jumlah siswa sebanyak 20 orang, yang terdiri dari 10 perempuan dan 10 laki-laki. Sedangkan objek penelitian ini adalah penerapan Strategi Pembelajaran Peningkatan Kemampuan Berpikir (SPPKB) untuk meningkatkan kemampuan pemecahan masalah pada siswa.

Penelitian ini merupakan penelitian tindakan kelas yang dilakukan dalam dua siklus dan setiap siklus dilaksanakan dalam dua kali pertemuan. Agar penelitian tindakan kelas ini berhasil dengan baik tanpa hambatan yang mengganggu kelancaran penelitian, peneliti menyusun tahapan-tahapan yang dilalui dalam penelitian tindakan kelas, yaitu: perencanaan tindakan, pelaksanaan tindakan, observasi dan refleksi. Adapun siklus penelitian tindakan kelas (PTK) menurut Suharsimi Arikunto dapat digambarkan sebagai berikut. (Suharsimi, 2019 : 42). 


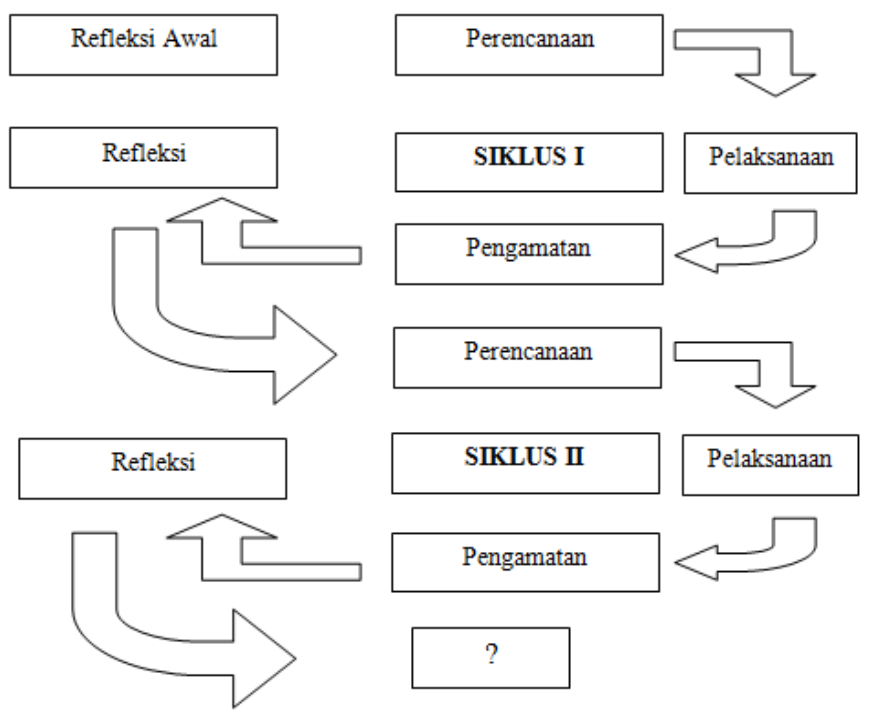

\section{Gambar 1. Alur Siklus Penelitian Tindakan Kelas (PTK)}

Dalam tahap perencanaan tindakan ini, langkah-langkah yang dilakukan adalah sebagai berikut: (a) Menyusun rencana pelaksanaan pembelajaran (RPP) berdasarkan silabus yang memuat Kompetensi Dasar (KD) dengan tindakan. (b) Mempersiapkan lembar observasi untuk mengamati aktivitas guru dan aktivitas belajar siswa selama proses pembelajaran melalui Strategi Pembelajaran Peningkatan Kemampuan Berpikir (SPPKB). (c) Menentukan observer.

Teknik pengumpulan data dalam penelitian ini adalah obserasi, tes, dan dokumentasi. Metode observasi dilakukan untuk mengamati aktivitas guru dan siswa selama pembelajaran penerapan Strategi Pembelajaran Peningkatan Kemampuan Berpikir (SPPKB). Tes merupakan instrument atau alat untuk mengumpulkan data tentang kemampuan subjek penelitian dengan cara pengukuran. Tes dilakukan untuk mengetahui kemampuan pemecahan masalah siswa setelah tindakan Siklus I dan Siklus II. Dokumentasi dilaksanakan dengan menyertakan data-data tentang sekolah, sejarah sekolah, keadaan guru dan siswa serta sarana dan prasarana yang ada disekolah serta dokumen yang berkitan seperti silabus, RPP, maupun nilai yang diperoleh siswa.

Teknik analisis data pada penelitian ini menggunakan teknik analisis deskriptif. Teknik ini dimulai dari menghimpun data, menyusun atau mengatur data, menyajika data dan menganalisis data angka guna memberikan gambaran suatu gejala, perisriwa atau keadaan. Untuk menentukan keberhasilan aktivitas guru dan aktivitas siswa selama proses pembelajaran diolah dengan menggunakan rumus persentase yaitu sebagai berikut:

Setelah data terkumpul melalui observasi, data tersebut diolah menggunakan rumus persentasi, yaitu sebagai berikut: 


$$
\mathrm{P}=\mathrm{F} / \mathrm{N} \times 100 \%
$$

Keterangan:

$\mathrm{P} \quad=$ Angka persentase

$\mathrm{F} \quad=$ Frekuensi yang dicari persentase

$\mathrm{N}=$ Number of cases (jumlah

frekuensi/banyak individu) $100 \%=$ Bilangan tetap

Dalam buku (Riduwan, 2010 : 15) menentukan kriteria penilaian tentang aktivitas guru dan siswa, maka dilakukan pengelompokan atas 5 kriteria yaitu sebagai berikut:

$$
\begin{array}{ll}
81 \%-100 \% & : \text { Sangat Tinggi } \\
61 \%-80 \% & : \text { Tinggi } \\
41 \%-60 \% & : \text { Cukup Tinggi } \\
21 \%-40 \% & : \text { Rendah } \\
0 \%-20 \% & : \text { Rendah Sekali }
\end{array}
$$

Untuk menentukan kemampuan pemecahan masalah matematika siswa ada beberapa langkah yang harus dilakukan. Adapun langkah-langkah yang dilakukan dalam pengolahan data kemampuan pemecahan masalah siswa adalah sebagai berikut: (1) Memberikan skor berdasarkan pedoman penskoran terhadap setiap pelaksanaan kemampuan pemecahan masalah siswa berdasarkan kriteria pada tabel 1. (2) Menghitung nilai akhir dengan rumus sebagai berikut:

$$
\text { Nilai }=\frac{\text { skor mentah yang diperoleh }}{\text { jumlah skor maksimum }} x 100 \%
$$

(3) Nilai kemampuan pemecahan masalah yang diperoleh dari perhitungan kemudian dikualifikasi sesuai dengan tabel 1.

Tabel 1. Kualifikasi Kemampuan Pemecahan Masalah Matematis Siswa

\begin{tabular}{cc}
\hline Nilai & Kualifikasi \\
\hline $85,00-100$ & Sangat Baik \\
$70,00-84,99$ & Baik \\
$55,00-69,99$ & Cukup Baik \\
$0-54,99$ & Kurang \\
\hline
\end{tabular}


Tabel 2. Pemberian Skor Pemecahan Masalah Matematika

\begin{tabular}{|c|c|c|}
\hline $\begin{array}{l}\text { Aspek } \\
\text { yang } \\
\text { Diambil }\end{array}$ & $\begin{array}{c}\text { Sko } \\
\text { r }\end{array}$ & Keterangan \\
\hline \multirow[t]{4}{*}{$\begin{array}{l}\text { Pemahaman } \\
\text { Masalah }\end{array}$} & 0 & $\begin{array}{l}\text { Salah menginterpretasikan soal atau tidak ada } \\
\text { jawaban } \\
\text { sama sekali }\end{array}$ \\
\hline & 1 & $\begin{array}{l}\text { Salah menginterpretasikan sebagian soal atau } \\
\text { mengabaikan kondisi soal }\end{array}$ \\
\hline & 2 & Memahami masalah atau soal selengkapnya \\
\hline & \multicolumn{2}{|c|}{ Skor maks $=2$} \\
\hline \multirow[t]{5}{*}{$\begin{array}{l}\text { Perencanaan } \\
\text { Penyelesaian }\end{array}$} & 0 & $\begin{array}{l}\text { Menggunakan strategi yang tidak relevan atau tidak } \\
\text { ada } \\
\text { strategi sama sekali }\end{array}$ \\
\hline & 1 & $\begin{array}{l}\text { Menggunakan satu strategi yang kurang dapat } \\
\text { dilaksanakan dan tidak dapat dilanjutkan }\end{array}$ \\
\hline & 2 & $\begin{array}{l}\text { Menggunakan sebagian strategi yang benar tapi } \\
\text { mengarah pada jawaban yang salah atau tidak } \\
\text { mencoba strategi yang lain }\end{array}$ \\
\hline & 3 & $\begin{array}{l}\text { Menggunakan beberapa strategi yang mengarah } \\
\text { pada } \\
\text { solusi yang benar }\end{array}$ \\
\hline & or & $s=3$ \\
\hline \multirow{5}{*}{$\begin{array}{l}\text { Pelaksanaa } \\
\text { n } \\
\text { Perhitunga } \\
\text { n }\end{array}$} & 0 & Tidak ada solusi sama sekali \\
\hline & 1 & $\begin{array}{l}\text { Menggunakan beberapa prosedur yang mengarah } \\
\text { pada } \\
\text { solusi yang benar }\end{array}$ \\
\hline & 2 & $\begin{array}{l}\text { Hasil salah atau sebagian hasil salah tetapi salah } \\
\text { perhitungan saja }\end{array}$ \\
\hline & 3 & Hasil dan proses benar \\
\hline & Skor $n$ & $s=3$ \\
\hline \multirow{4}{*}{$\begin{array}{l}\text { Pemeriksaan } \\
\text { kembali hasil } \\
\text { perhitungan }\end{array}$} & & $\begin{array}{l}\text { Tidak ada pemeriksaan atau tidak ada keterangan } \\
\text { Apapun }\end{array}$ \\
\hline & 1 & Ada pemeriksaan tetapi tidak tuntas \\
\hline & & $\begin{array}{l}\text { Pemeriksaan dilaksanakan untuk melihat hasil dan } \\
\text { Proses }\end{array}$ \\
\hline & $\mathrm{Sk}$ & $s=2$ \\
\hline
\end{tabular}

\section{HASIL DAN PEMBAHASAN}

\section{Hasil Penelitian}

Data hasil kemampuan pemecahan masalah siswa sebelum tindakan, peneliti peroleh dari melaksanakan tes dengan menggunakan strategi dan metode ceramah serta latihan yang biasa digunakan dalam proses pembelajaran. Dari penerapan pembelajaran diketahui kemampuan pemecahan masalah siswa tergolong rendah. Untuk lebih jelas dapat dilihat pada tabel berikut. 
Tabel 3. Kemampuan Pemecahan Masalah Siswa Sebelum Tindakan

\begin{tabular}{lccc}
\hline \multicolumn{1}{c}{ Sub Aspek } & Jumlah Skor & Persentase & Kategori \\
\hline Pemahaman masalah & 150 & $75 \%$ & Cukup Baik \\
Perencanaan penyelesaian & 170 & $57 \%$ & Kurang Baik \\
Pelaksanaan perhitungan & 170 & $57 \%$ & Kurang Baik \\
Pemeriksaan kembali hasil & & $40 \%$ & Kurang Sekali \\
Perhitungan & 80 & $228 \%$ & \\
\hline Jumlah & 570 & $57 \%$ & Kurang Baik \\
Rata-rata & 142,5 & & \\
\hline
\end{tabular}

Berdasarkan tabel 3 hampir setiap sub aspek kemampuan pemecahan masalah masih tergolong rendah hanya kemampuan pemahaman masalah yang terkategori cukup baik dengan persentase $75 \%$, hal ini terjadi karena guru menggunakan metode ceramah untuk menjelaskan faktor persekutuan terbesar dua bilangan sehingga siswa hanya mengetahui masalah yang ditanya dari soal tersebut. Namun siswa kurang dalam kemampuan pemeriksaan kembali hasil perhitungan yang hanya memperoleh persentase $40 \%$ sebab tidak muncul dalam pembelajaran. Hal ini dikarenakan tidak ada kegiatan pemecahan masalah dalam pembelajaran sehingga kemampuan pemecahan masalah siswa tergolong rendah.

\section{Tabel 4. Hasil Tes Kemampuan Pemecahan Masalah Matematika Siswa Pra} Tindakan

\begin{tabular}{|c|c|c|c|c|}
\hline No & Nilai & & & Keterangan \\
\hline & & $\mathrm{F}$ & $\%$ & \\
\hline 1 & $\square 70$ & 3 & $15 \%$ & Baik \\
\hline
\end{tabular}

Berdasarkan tabel 4, dari 20 siswa hanya 3 orang siswa yang memperoleh kualifikasi kemampuan pemecahan masalah kategori baik dengan persentase $15 \%$, artinya pada tes sebelum tindakan hanya 3 orang siswa yang memiliki kemampuan pemecahan masalah dengan kualifikasi baik, sedangkan siswa yang lain belum memiliki kemampuan pemecahan masalah yang baik. Hal ini dikarenakan dalam proses belajar guru tidak pernah melibatkan siswa dalam kegiatan pemecahan masalah, bahkan pada tes maupun ujian tidak ada soal yang mengarahkan siswa untuk memecahkan masalah.

\section{Siklus I}

\section{Perencanaan Tindakan}

Siklus I untuk pertemuan pertama dilaksanakan pada tanggal 7 Januari 2020 dan pertemuan kedua pada tanggal 9 Januari 2020 . Jadwal penelitian ini sesuai dengan jadwal pelajaran yang ditetapkan di Madrasah Ibtidaiyah Al Wathaniyah Tualang, yang mana dalam satu minggu terdapat 5 jam mata pelajaran Matematika di kelas IV yang berbeda 
harinya. Pelaksanaan pembelajaran berpedoman pada silabus dan RPP berdasarkan standar kompetensi dengan menggunakan strategi pembelajaran peningkatan kemampuan berpikir, menyusun lembar observasi aktivitas guru dan aktivitas siswa dengan meminta wali kelas dan teman sejawat untuk menjadi observer. Lalu menyusun daftar pertanyaan yang akan dilontarkan kepada siswa, menyusun alat evaluasi untuk mengukur peningkatan kemampuan pemecahan masalah siswa dalam mencapai kompetensi dasar. Setelah merencanakan dan menyusun segala yang dibutuhkan dalam penelitian maka dilanjutkan dengan pelaksanaan tindakan.

\section{Pelaksanaan Tindakan Pertemuan Pertama}

Siklus I untuk pertemuan pertama dilaksanakan pada tanggal 7 Januari 2020. Indikator yang harus dicapat pada pertemuan pertama adalah menjelaskan faktor persekutuan dua bilangan dan menyebutkan faktor persekutuan dua bilangan. Pada kegiatan awal, guru datang ke kelas dan memberi salam kepada siswa yang ada di dalam kelas. Selanjutnya guru menyampaikan tujuan yang akan dicapai dan memberikan penjelasan tentang materi yang akan dipelajari. Kemudian guru menjelaskan tahap strategi pembelajaran peningkatan kemampuan berpikir. (Tahap Orientasi)

Pada kegiatan inti tahap selanjutnya, guru menanyakan mengenai materi sebelumnya dan mengkaitkan dengan materi yang akan dipelajari hari ini. Kemudian guru memberikan pertanyaan untuk mengetahui pemahaman siswa tentang faktor persekutuan dua bilangan. Seluruh siswa menjawab "kami tidak tahu mengenai itu umi, karena kami belum pernah mempelajarinya". Kemudian guru menanyakan berapa jumlah seluruh siswa di dalam kelas, salah satu siswa menjawab "kami berjumlah 20 orang umi". Kemudian guru meminta siswa untuk berdiri dan membentuk kelompok dengan jumlah siswa sama rata, seketika siswa membentuk 2 kelompok dengan jumlah siswa 10 orang setiap kelompok. (Tahap Pelacakan)

Kemudian guru meminta siswa agar membentuk kelompok lagi dengan jumlah siswa sama rata, seketika siswa membentuk 4 kelompok dengan jumlah siswa 5 orang setiap kelompok. Kemudian guru bertannya "selain 2 kelompok dan 5 kelompok, berapa kelompok lagi yang dapat kita bentuk dengan jumlah siswa sama rata?", seketika siswa menjawab " 5 kelompok dengan jumlah siswa 4 orang setiap kelompok umi, 10 kelompok dengan jumlah siswa 2 orang setiap kelompok umi, 1 kelompok dengan jumlah siswa 20 orang umi. Kemudian guru bertanya apakah kita dapat membaginya dalam 6 kelompok, dengan serentak siswa menjawab "tidak bisa umi, karena tidak akan sama rata". (Tahap Konfrontasi)

Pada tahap selanjutnya, guru menuliskan di papan tulis jumlah kelompok yang telah disebutkan tadi dan mengatakan bahwa bilangan tersebut $(1,2,4,5,10,20)$ merupkan faktor bilangan dari 20. Kemudian guru memberikan kesempatan kepada siswa untuk memikirkan apa yang dimaksud dengan faktor bilangan. Setelah beberapa lama berpikir dan dengan dorongan motivasi dari guru siswa pun satu persatu memberanikan diri untuk menjawab pertanyaan guru. Siswa 020 menyebutkan "faktor bilangan itu adalah bilangan yang dapat dibagi dengan bilangan 20 umi", Siswa 017 menyebutkan "faktor bilangan itu 
adalah bilangan yang habis dibagi umi". Kemudian guru memberikan kata kunci atas jawaban siswa, lalu siswa menyimpulkan secara bersama. Setelah itu, guru mengkonfirmasi kesimpulan yang dilontarkan siswa, faktor bilangan adalah "suatu bilangan yang dapat habis membagi bilangan tersebut”. (Tahap Inkuiri dan Tahap Akomodasi)

Pada tahap selanjutnya, guru menunjukkan dua bungkus permen dengan rasa strowberi dan anggur dengan masing-masing permen berjumlah strowberi 12 butir dan anggur 18 butir. Kemudian guru memberikan pertanyaan berapa banyak siswa yang akan memperoleh permen rasa strowberi dan anggur dan berapa jumlah permen strowberi dan anggur yang akan diperoleh masing-masing siswa. (Tahap Konfrontasi)

Setelah itu, guru meminta kepada siswa yang dapat menjawab agar maju kedepan dan langsung membagi permen tersebut dengan temannya sesuai dengan jawaban siswa. Setelah beberapa siswa menjawab dengan jawaban kurang tepat, lalu guru meminta siswa terlebih dahulu mencari faktor bilangan dari 12 dan 18. Setelah faktor dua bilangan telah ditemukan lalu guru meminta siswa untuk melingkari bilangan yang sama diantara kedua faktor bilangan tersebut. Kemudian guru mengatakan bahwa bilangan yang telah mereka lingkari merupakan faktor persekutuan dua bilangan.

Selanjutnya guru menanyakan kembali apa yang dimaksud dengang faktor persekutuan dua bilangan. Seketika semua siswa mengatakan dengan pendapat yang berbeda-beda. Siswa 008 menyebutkan "faktor persekutuan adalah bilangan yang sama umi" , Siswa 014 menyebutkan "faktor persekutuan itu faktor bilangan yang sama dari dua bilangan umi”. (Tahap Inkuiri)

Setelah beberapa siswa menyampaikan jawabannya guru bersama siswa membuat kesimpulan agar tidak terjadi kesalah konsep dalam memahami faktor persekutuan dua bilangan. Kesimpulannya adalah faktor persekutuan dua bilangan merupakan bilangan yang sama yang dapat habis membagi dua bilangan atau lebih. (Tahap Akomodasi)

Pada tahap kegiatan penutup guru membagikan lembar kerja siswa atau soal tes pemecahan masalah yang akan dikerjakan siswa secara individu. Selama siswa melakukan kegiatan, guru memberikan bimbingan dan arahan kepada siswa yang mendapat kesulitan dalam memecahkan masalah. Setelah selesai dikerjakan, guru mengumpulkan masing-masing jawaban siswa dan memberikan hadiah permen rasa strowberi dan anggur kepada siswa yang mengerjakan dengan cepat. Kemudian guru berama siswa menyimpulkan pelajaran. Selanjutnya guru memberikan pekerjaan rumah (PR) kepada siswa dengan minta siswa untuk meringkas dan membaca materi mengenai FPB. Ini merupakan indikator yang akan dipelajari pada pertemuan berikutnya. (Tahap Transfer)

\section{Pertemuan Kedua}

Pada pertemuan kedua untuk siklus I dilakukan pada tanggal 9 Januari 2020. Indikator yang harus dicapai pada pertemuan kedua adalah menentukan faktor persekutuan terbesar dari dua bilangan dan menggunakan faktorisasi prima untuk menentukan FPB dari beberapa bilangan. Pada kegiatan awal, guru datang ke kelas dan 
memberi salam kepada siswa yang ada di dalam kelas. Selanjutnya guru menyampaikan tujuan yang akan dicapai dan memberikan penjelasan tentang materi yang akan dipelajari. Kemudian guru menjelaskan kembali tahap strategi pembelajaran peningkatan kemampuan berpikir. (Tahap Orientasi)

Pada kegiatan inti tahap pertama, guru menanyakan mengenai materi sebelumnya dan mengkaitkan dengan materi yang akan dipelajari hari ini. Kemudian guru bertanya apa yang dimaksud dengan faktor persekutuan terbesar (FPB), sebagian besar siswa terdiam dan menunjukkan wajah ketidak tahuan mereka mengenai FPB. Namun ada beberapa siswa menjawab dengan membaca buku ringkasan mengenai materi FPB yang telah ditugaskan guru sebagai PR. (Tahap Pelacakan)

Pada tahap selanjutnya, guru menunjukkan dua bungkus permen dengan rasa strowberi dan anggur dengan masing-masing permen berjumlah strowberi 12 butir dan anggur 18 butir. Kemudian guru memberikan pertanyaan berapa banyak siswa yang akan memperoleh permen rasa strowberi dan anggur dan berapa jumlah permen strowberi dan anggur yang akan diperoleh masing-masing siswa. (Tahap Konfrontasi)

Setelah itu, guru meminta kepada siswa yang dapat menjawab agar maju kedepan dan langsung membagi permen tersebut dengan temannya sesuai dengan jawaban siswa. Setelah beberapa siswa menjawab dengan jawaban kurang tepat, lalu guru meminta siswa terlebih dahulu mencari faktor bilangan dari 12 dan 18. Setelah faktor dua bilangan telah ditemukan (faktor $12=1,2,3,4,6,12$ dan faktor $18=1,2,3,6,9,18$ ) lalu guru meminta siswa untuk melingkari bilangan yang sama diantara kedua faktor bilangan tersebut $(\mathrm{FP}=$ 1,2,3,6). Kemudian guru mengatakan bahwa bilangan yang telah mereka lingkari merupakan faktor persekutuan dua bilangan. Setelah itu guru meminta siswa untuk melingkari kembali bilangan terbesar dari fakror persekutuan dua bilangan tersebut $(\mathrm{FPB}=6)$. (Tahap Inkuiri)

Kemudia guru menyebutkan bahwa bilangan terbesar yang sama dari faktor kedua bilangan merupakan faktor persekutuan terbesar (FPB). Selanjutnya guru meminta siswa untuk dapat mengemukan apa yang dimaksud dengan FPB. Siswa 003 menjelaskan dari kesimpulan yang telah ia tuliskan dibuku "FPB adalah bilangan yang sama yang dapat habis membagi dua bilangan tetapi bilang yang terbesar umi". Siswa 018 mengatakan "FPB adalah 6 umi". Semua siswa menjawab "memang FPB itu 6 tapi bukan itu jawabannya". Guru mengkonfirmasi bahwa memang benar yang dikatakan Siswa 018, tetapi kurang tepat jawaban yang dikatakaan Siswa 018. Kemudian guru bersama siswa membuat kesimpulan bahwa FPB adalah faktor persekutuan yang nilainya terbesar diantara faktor-faktor persekutuan lainnya. (Tahap Akomodasi)

Pada tahap kegiatan penutup guru membagikan lembar kerja siswa atau soal tes pemecahan masalah yang akan dikerjakan siswa secara individu. Selama siswa melakukan kegiatan, guru memberikan bimbingan dan arahan kepada siswa yang mendapat kesulitan dalam memecahkan masalah. Setelah selesai dikerjakan, guru mengumpulkan masing-masing jawaban siswa dan memberikan hadiah bintang kepada siswa yang mengerjakan dengan cepat dan kemudian bintang tersebut akan ditempelkan didinding prestasi siswa. Kemudian guru bersama siswa menyimpulkan pelajaran. Selanjutnya guru 
memberikan pekerjaan rumah (PR) kepada siswa dengan minta siswa untuk meringkas dan membaca materi mengenai kelipatan persekutuan dua bilangan. Ini merupakan indikator yang akan dipelajari pada pertemuan berikutnya. (Tahap Transfer)

\section{Observasi}

Observasi yang telah dilakukan dalam penelitian ini dipusatkan pada proses maupun hasil tindakan pembelajaran yang diamati dalam aktivitas guru dan aktivitas siswa selama proses belajar mengajar berlangsung., untuk lebih jelas dapat diliht pada tabel berikut.

\section{Aktivitas Guru}

Berdasarkan hasil observasi terhadap aktivitas guru yang telah dilakukan, pelaksanaan penerapan SPPKB telah dilakukan dengan langkah-langkah yang telah di suusn dalam RPP siklus I pertemuan pertama. Namun masih berada dalam kategori "Rendah". Hal ini di ukur berdasarkan indikator aktivitas guru antara rentang persen 21\%-40\%, meningkat pada pertemuan kedua dengan persentase $60 \%$ kategori "Cukup Tinggi”

Kegiatan yang dilakukan guru dalam poin 1 adalah menjelaskan tujuan dan melanjutkan materi, dalam hal ini guru mendapatkan skor 2 (kurang baik) karena dalam pelaksanaan guru kurang jelas dalam menyampaikan tujuan sehingga siswa kurang mengetahui tujuan yang akan dicapai dalam pembelajaran. Selain itu dalam mengkaitkan materi sebelumnya dengan materi yang akan dipelajari, hal ini guru kurang tepat dalam mengkaitkannnya. Pada poin 2 guru mendapatkan skor 1 (sangat kurang), karena guru belum menguasai strategi ini dengan baik. Sedangkan pada tahap pelacakan poin Tiga orang guru mendapatkan skor 3 (cukup baik), karena guru telah memberikan pertanyaan untuk mengetahui pemahan kemampuan dasar siswa, hanya saja pertanyaan yang guru ajukan kurang menyeluruh kepada siswa. Dalam kegiatan tahap konfrontasi dan inkuiri guru hanya memfokuskan kepada siswa siswa yang aktif dalam belajar, jadi terlihat dalam proses pembelajaran hanya siswa- siswa itu saja yang aktif sedangkan siswa yang lain hanya diam dan mendengarkan bahkan sibuk dengan kegiatan diluar pembelajaran. Dalam hal ini guru mendapatkan skor 2 (kurang baik). Pada tahap akomodasi guru mendapatkan skor 2 (kurang baik) karena dalam kegiatan ini guru kurang memberi kesempatan kepada siswa untuk mengemukakan hasil kesimpulan dari pemecahan masalah, begitu juga dalam tahap transfer guru mendapatkan skor 2 (kurang baik) karena dalam pelaksanaannya guru kurang jelas dalam memberikan tugas sesuai materi yang dipelajari sekaligus sebagai evaluasi untuk mengetahui kemampuan pemecahan masalah siswa. Hasil observasi aktivitas guru siklus I dapat dilihat pada tabel berikut:

Tabel 5. Hasil Observasi Aktivitas Guru Pada Siklus I (Pertemuan 1 dan 2) 


\begin{tabular}{|c|c|c|c|c|}
\hline No & Aktivitas Guru & Skor pert. & $\begin{array}{l}\text { Skor } \\
\text { pert. } 2\end{array}$ & $\begin{array}{l}\text { Total } \\
\text { Skor } \\
\text { Siklus I } \\
\end{array}$ \\
\hline 1. & $\begin{array}{l}\text { Guru menjelaskan tujuan yang akan dicapai dan } \\
\text { melanjutkan materi pada pertemuan yang } \\
\text { sebelumnya. }\end{array}$ & 2 & 3 & 5 \\
\hline 2. & $\begin{array}{l}\text { Guru menjelaskan proses pembelajaran yang harus } \\
\text { dilakukan dalam setiap tahapan proses pembelajaran. }\end{array}$ & 1 & 4 & 5 \\
\hline 3. & $\begin{array}{l}\text { Guru melakukan tahap pelacakan dengan } \\
\text { memberikan pertanyaan untuk pemahaman } \\
\text { kemampuan dasar siswa. }\end{array}$ & 3 & 3 & 6 \\
\hline 4. & $\begin{array}{l}\text { Guru melakukan tahap konfrontasi dengan } \\
\text { memberikan pertanyaan yang sampai akhirnya pada } \\
\text { pemecahan masalah. }\end{array}$ & 2 & 3 & 5 \\
\hline 5. & $\begin{array}{l}\text { Guru melakukan tahap Inkuiri dengan memberikan } \\
\text { kesempatan kepada siswa untuk memecahkan } \\
\text { masalah. }\end{array}$ & 2 & 3 & 5 \\
\hline 6. & $\begin{array}{l}\text { Guru melakukan tahap Akomodasi dengan } \\
\text { memberikan kesempatan kepada siswa } \\
\text { mengemukakan hasil kesimpulan dari pemecahan } \\
\text { masalah. }\end{array}$ & 2 & 2 & 4 \\
\hline 7. & $\begin{array}{l}\text { Guru melakukan tahap transfer dengan memberikan } \\
\text { tugas sesuai pembahasan dan sekaligus evaluasi. }\end{array}$ & 2 & 3 & 5 \\
\hline & $\begin{array}{c}\text { Total } \\
\text { Persentase }\end{array}$ & $\begin{array}{c}14 \\
40 \%\end{array}$ & $\begin{array}{c}21 \\
60 \%\end{array}$ & $\begin{array}{c}35 \\
50 \%\end{array}$ \\
\hline
\end{tabular}

\section{Aktivitas Siswa}

Aktivitas siswa siklus I pertemuan pertama dengan persentase tertinggi yaitu $100 \%$, terjadi ketika siswa mengerjakan tugas dari guru tentang materi yang telah diajarkan sebagai evaluasi. Walaupun siswa masih kebingungan dalam menjawab soal pemecahan masalah yang telah diberikan oleh guru. Persentase paling rendah dengan total $30 \%$, terjadi saat siswa mendengarkan penjelasan guru tentang tujuan pembelajaran yang akan dicapai dan siswa menjawab pertanyaan guru sesuai kemampuan dasarnya. Ini terjadi karena sebagian besar siswa tidak mendengarkan tujuan pembelajaran yang disampaikan guru sehingga berdampak pada rendahnya aktivitas siswa. Selain itu sebagian siswa juga kesulitan dalam menjawab pertanyaan guru dan beberapa siswa menjawab pertanyaan yang diberikan dengan bahasa buku karena siswa tersebut membaca buku yang terdapat diatas mejanya. Sehingga persentase pada aktivitas ini tergolong rendah.

Aktivitas siswa siklus I pertemuan kedua dengan persentase tertinggi yaitu $100 \%$ atau tergolong "Sangat Tinggi", terjadi ketika siswa mengerjakan tugas dari guru tentang materi yang telah diajarkan sebagai evaluasi. Walaupun siswa masih kebingungan dalam menjawab soal pemecahan masalah yang telah diberikan oleh guru. Persentase paling rendah dengan total 55\% atau tergolong "Cukup Tinggi", terjadi ketika siswa menjawab pertanyan-pertanyaan guru yang akhirnya sampai pada pemecahan masalah, hal ini terjadi karena sebagian besar siswaa takut untuk menyampaikan jawabannya dan memilih diam 
dan mendengarkan jawaban dari teman yang aktif menjawab pertanyaan yang diberikan guru.

Tabel 6. Hasil Observasi Aktivitas Siswa Pada Siklus I (Pertemuan 1 dan 2)

\begin{tabular}{|c|c|c|c|c|c|c|c|}
\hline \multirow[t]{2}{*}{ No } & \multirow[t]{2}{*}{ Aktivitas yang diamati } & \multicolumn{2}{|c|}{ Skor Pert. 1} & \multicolumn{2}{|c|}{ Skor Pert. 2} & \multicolumn{2}{|c|}{$\begin{array}{c}\text { Total } \\
\text { Rata-rata }\end{array}$} \\
\hline & & Jumlah & $\%$ & Jumlah & $\%$ & Jumlah & $\%$ \\
\hline 1 & $\begin{array}{l}\text { Siswa mendengarkan penjelasan } \\
\text { guru tentang tujuan } \\
\text { pembelajaran vang akan dicapai. }\end{array}$ & 6 & $30 \%$ & 13 & $65 \%$ & 9,5 & $48 \%$ \\
\hline 2 & $\begin{array}{l}\text { Siswa memperhatikan } \\
\text { penjelasan guru tentang proses } \\
\text { pembelajaran yang harus } \\
\text { dilakukan dalam setiap tahapan } \\
\text { proses pembelajaran. }\end{array}$ & 10 & $50 \%$ & 13 & $65 \%$ & 11,5 & $58 \%$ \\
\hline 3 & $\begin{array}{l}\text { Siswa menjawab pertanyaan } \\
\text { guru sesuai kemampuan } \\
\text { dasarnya. }\end{array}$ & 6 & $30 \%$ & 13 & $65 \%$ & 9,5 & $48 \%$ \\
\hline 4 & $\begin{array}{l}\text { Siswa menjawab pertanyaan- } \\
\text { pertanyaan guru yang akhirnya } \\
\text { sampai pada pemecahan } \\
\text { masalah. }\end{array}$ & 7 & $35 \%$ & 11 & $55 \%$ & 9 & $45 \%$ \\
\hline 5 & $\begin{array}{l}\text { Siswa terlibat dalam pemecahan } \\
\text { masalah matematika. }\end{array}$ & 7 & $35 \%$ & 12 & $60 \%$ & 9,5 & $48 \%$ \\
\hline 6 & $\begin{array}{l}\text { Siswa dapat mengemukakan } \\
\text { hasil kesimpulan dari masalah } \\
\text { yang timbul. }\end{array}$ & 7 & $35 \%$ & 13 & $65 \%$ & 10 & $50 \%$ \\
\hline 7 & $\begin{array}{l}\text { Siswa mengerjakan tugas dari } \\
\text { guru tentang materi yang telah } \\
\text { diajarkan sebagai evaluasi. }\end{array}$ & 20 & $100 \%$ & 20 & $100 \%$ & 20 & $100 \%$ \\
\hline & Jumlah & 63 & $45 \%$ & 95 & $68 \%$ & 56 & \\
\hline & Kategori & Cukup & inggi & Tin & & Cukup & inggi \\
\hline
\end{tabular}

\section{Kemampuan Pemecahan Masalah}

\section{Tabel 7. Kemampuan Pemecahan Masalah Siswa Siklus I}

\begin{tabular}{lccc}
\hline \multicolumn{1}{c}{ Sub Aspek } & Jumlah Skor & Persentase & Kategori \\
\hline Pemahaman masalah & 53 & $88 \%$ & Sangat Baik \\
Perencanaan penyelesaian & 77 & $86 \%$ & Sangat Baik \\
Pelaksanaan perhitungan & 57 & $63 \%$ & Cukup Baik \\
$\begin{array}{l}\text { Pemeriksaan kembali hasil } \\
\text { perhitungan }\end{array}$ & 40 & $66 \%$ & Cukup Baik \\
\hline Jumlah & 226 & & \\
Rata-rata & 56,5 & $75,6 \%$ & Baik \\
\hline
\end{tabular}


Pada tabel 7 terlihat bahwa nilai aspek kemampuan pemecahan masalah Matematika siswa menggunakan strategi pembelajaran peningkatan kemampuan berpikir pada siklus I bervariasi pada setiap subaspek. Persentase terendah terjadi pada aspek pelaksanaan perhitungan 63\% dan. Hal ini terjadi karena siswa tidak memeriksa kembali hasil perhitungan yang telah dilakukan sehingga banyak siswa yang salah dalam melaksanakan perhitungan.

\section{Tabel 8. Hasil Tes Kemampuan Pemecahan Masalah Matematika Siswa Siklus I}

\begin{tabular}{cclcc}
\hline No & \multicolumn{1}{c}{ Nilai } & \multicolumn{2}{c}{ Siklus I } & Keterangan \\
& & \multicolumn{1}{c}{ F } & $\%$ & \\
\hline 1 & $\square 70$ & 14 & $70 \%$ & Baik \\
2 & $<70$ & 6 & $30 \%$ & Cukup/Kurang \\
\hline
\end{tabular}

Berdasarkan tabel 8 diketahui rata-rata persentase yang diperoleh dari hasil kemampuan pemecahan masalah siswa pada siklus I (tes siklus) yang diambil dari tes kemampuan pemecahan masalah siswa dengan strategi pembelajaran peningkatan kemampuan berpikri SPPKB diketahui bahwa dari 20 orang siswa hanya 14 orang siswa yang mencapai nilai kemampuan pemecahan masalah yang baik dengan persentase klasikal adalah $70 \%$, sedangkan yang tidak mencapai nilai kemampuan pemecahan masalah yang baik sebanyak 6 orang siswa dengan persentase 30\%. Hal ini berarti siswa kelas IV A Madrasah Ibtidaiyah Al-Wathaniyah belum mencapai indikator keberhasilan kemampuan pemecahan masalah yang ditetapkan yaitu $75 \%$ dari jumlah keseluruhan siswa. Untuk itu peneliti akan memperbaiki kegagalan yang dialami siswa melalui penelitian tindakan kelas dengan melakukan tindakan pada siklus kedua, untuk lebih meningkatkan kemampuan pemecahan masalah siswa melalui strategi pembelajaran peningkatan kemampuan berpikir.

\section{Refleksi}

Setelah dilakukan tindakan melalui strategi pembelajaran peningkatan kemampuan berpikir pada pertemuan siklus I dan diamati oleh observer, selanjutnya peneliti melakukan refleksi yang tujuannya untuk memperbaiki kesalahan dan kelemahan yang terjadi pada pertemuan siklus I. Berdasarkan hasil pembahasan peneliti dan observer pada pertemuan siklus I, ditemukan beberapa kekurangan pada pelaksanaan strategi pembelajaran peningkatan kemampuan berpikir adalah sebagai berikut: (1) Saat tahap pelacakan pertanyaan yang guru ajukan kepada siswa kurang merata sehingga tidak semua siswa yang menjawab pertanyaa yang guru berikan. (2) Pada saat konfrontasi, memberi pertanyaan yang sampai akhirnya pada pemecahan masalah guru menggunakan bahasa yang komunikatif sehingga siswa kurang mengerti pertanyaan yang guru ajukan. Seperti guru menanyakan faktorisasi dan faktor bilangan. (3) Pada tahap inkuiri dengan memberikan kesempatan kepada murid untuk memecahkan masalah, tidak semua siswa dapat memecahkan masalah, hanya siswa yang aktif dan berani untuk memecahkan masalah yang ada. (4) Banyak siswa yang merasa kebingungan dalam menjawab soal 
pemecahan masalah. (5) Dalam pengelolaan waktu, guru terlalu lama dalam memberikan waktu kepada siswa untuk memecahkan masalah sehingga pada waktu untuk tahap akomodasi dengan memberikan kesempatan kepada siswa mengemukakan hasil kesimpulan dari pemecahan masalah terlalu sedikit, menyebabkan siswa kurang paham dengan materi.

Berdasarkan hasil refleksi siklus I peneliti menyusun rencana untuk perbaikan yang akan dilaksanakan pada siklus II yaitu: (1) Guru akan lebih menyeluruh dan merata dalam memberikan pertanyaan sehingga semua siswa akan menjawab pertanyaan guru tentang kemampuan dasar siswa.

(2) Guru akan memilih kata-kata yang sesuai denga taraf linguistik siswa sehingga siswa akan paham dengan pertanyaan yang guru ajukan dan guru akan memberi penjelasan mengenai kata-kata yang tidak dipahami oleh siswa. (3) Guru tidak hanya terfokus pada siswa yang aktif saja tapi guru juga akan melibatkan siswa yang kurang aktif untuk memecahkan masalah. Sehingga semua siswa aktif dalam memecahkan masalah. (4) Guru akan memberi bimbingan saat siswa kesulitan menjawab soal pemecahan masalah. Secara klasikal guru akan membantu siswa menjawab soal pemecahan masalah dengan mengerjakan contoh soal secara bersama. (5) Guru akan mengatur waktu dengan baik. Sehingga siswa memiliki kesempatan mengemukakan hasil kesimpulan dari pemecahan masalah.

\section{Siklus II}

\section{Perencanaan Tindakan}

Siklus II untuk pertemuan ketiga dilaksanakan pada tanggal 13 Januari 2020 dan pertemuan keempat pada tanggal 16 Januari 2020 . Jadwal penelitian ini sesuai dengan jadwal pelajaran yang ditetapkan di Madrasah Ibtidaiyah Al Wathaniyah Tualang, yang mana dalam satu minggu terdapat 5 jam mata pelajaran Matematika di kelas IV yang berbeda harinya. Pelaksanaan pembelajaran berpedoman pada silabus dan RPP berdasarkan standar kompetensi dengan menggunakan strategi pembelajaran peningkatan kemampuan berpikir, menyusun lembar observasi aktivitas guru dan aktivitas siswa dengan meminta wali kelas dan teman sejawat untuk menjadi observer.

\section{Pelaksanaan Tindakan Pertemuan Ketiga}

Siklus II untuk pertemuan ketiga dilaksanakan pada tanggal 13 Januari 2020. Materi yang dibahas pada siklus II tentang kelipatan persekutuan terkecil (KPK). Indikator yang harus dicapai pada pertemuan ketiga adalah menjelaskan dan menyebutkan kelipatan persekutuan dua bilangan. Pada kegiatan awal, guru datang ke kelas dan memberi salam kepada siswa yang ada di dalam kelas. Selanjutnya guru menyampaikan tujuan yang akan dicapai dan memberikan penjelasan tentang materi yang akan dipelajari. Kemudian guru menjelaskan tahap strategi pembelajaran peningkatan kemampuan berpikir. (Tahap Orientasi) 
Pada kegiatan inti tahap selanjutnya, guru menanyakan mengenai materi sebelumnya dan mengkaitkan dengan materi yang akan dipelajari hari ini. Kemudian guru memberikan pertanyaan untuk mengetahui pemahaman siswa tentang kelipatan persekutuan dua bilangan. Sebagian besar siswa menjawab "tidak tahu umi". Sampoerna menjawab "perkalian yang sama umi". Agar tidak terjadi kesalahan konsep, guru bertanya kepada siswa mengenai kelipatan dari 2. Seluruh siswa menjawab "2,4,6,8,10,12,14 dan seterusnya". Kemudian guru bertanya lagi kelipatan dari 3. Sebagian besar siswa menjawab "3,6,9,12,15 dan seterusnya". (Tahap Pelacakan)

Selanjutnya guru mengajak siswa untuk bermain tepuk tangan gembira. Guru menjelaskan cara bermain tepuk tangan gembira, ketika guru mengatakan kelipatan dua makan seluruh siswa bertepuk tangan apabila guru menyebutkan bilangan dari kelipatan dua, namun sebaliknya apabila guru tidak menyebutkan bilangan dari kelipatan dua maka siswa tidak boleh bertepuk tangan. Saat bermain guru menyebutkan bilangan 4 kemudian seluruh siswa bertepuk tangan, lalu guru menyebutkan bilangan 9 sebagian besar siswa tidak bertepuk tangan, namun ada beberapa siswa bertepuk tangan. Lalu guru bertanya kepada siswa mengapa mereka tidak bertepuk tangan ketika bilangan 9 disebutkan oleh guru, kemudian beberapa siswa menjawab "karena 9 bukan kelipatan 2". (Tahap Konfrontasi)

Selanjutnya guru menjelaskan kembali cara bermain sehingga seluruh siswa memahami cara bermain tepuk tangan gembira. Permainan dilanjutkan dengan membagi siswa dalam 2 kelompok, kemudian masing-masing kelompok diberikan kelipatan yang berbeda. Kelompok A diberikan kelipatan 2 dan kelompok B diberikan kelipatan 3. Selanjutnya guru menyebutkan bilangan 8 sontak kelompok A bertepuk tangan, kemudian guru menyebutkan bilangan 9 sontak kelompok B bertepuk tangan, lalu guru menyebutkan bilangan 612 dan 18 secara berurutan sontak kelompok A dan B bertepuk tangan secara bersamaan. Guru bertanya mengapa kelompok A dan B bertepuk tangan secara bersama ketika guru menyebutkan bilangan 612 dan 18. Siswa 014 menyebutkan "karena bilangan tersebut merupakan bilangan dari kelipatan 2 dan 3 umi". Siswa 020 menyebutkan "karena bilangan tersebut merupakan kelipatan yang sama umi”. (Tahap Inkuiri)

Pada tahap selanjutnya guru bertanya apa yang dimaksud dengan kelipatan bilangan. Dari permainan tepuk tangan gembira sebagian siswa dapat mengetahui apa yang dimaksud dengan kelipatan. Siswa 013 menyebutkan "kelipatan adalah hasil perkalian bilangan tersebut dengan bilangan 12234 dan seterusnya umi”. Bintang menyebutkan " hasil penjumlahan bilangan tersebut umi". Kemudian guru bersama siswa menyimpulkan pengertian dari kelipatan bilangan. Selanjutnya guru bertanya kembali apa yang dimaksud dengan kelipatan persekutuan dua bilangan. Seluruh siswa menjawab "hasil perkalian dua bilangan yang sama umi”. Kemudian guru bersama siswa menyimpulkan pengertian dari kelipatan persekutuan dua bilangan. (Tahap Akomodasi)

Pada tahap kegiatan penutup guru membagikan lembar kerja siswa atau soal tes pemecahan masalah yang akan dikerjakan siswa secara individu. Selama siswa melakukan kegiatan, guru memberikan bimbingan dan arahan kepada siswa yang mendapat kesulitan dalam memecahkan masalah. Setelah selesai dikerjakan, guru mengumpulkan masing- 
masing jawaban siswa dan memberikan hadiah kue kepada siswa yang mengerjakan dengan cepat. Kemudian guru berama siswa menyimpulkan pelajaran. Selanjutnya guru memberikan pekerjaan rumah (PR) kepada siswa dengan minta siswa untuk meringkas dan membaca materi mengenai KPK. Ini merupakan indikator yang akan dipelajari pada pertemuan berikutnya. (Tahap Transfer)

Pada pertemuan keempat untuk siklus II dilakukan pada tanggal 16 Januari 2020. Indikator yang harus dicapai pada pertemuan keempat adalah menentukan kelipatan persekutuan terkecil dari dua bilangan dan menggunakan faktorisasi prima untuk menentukan KPK dari beberapa bilangan. Pada kegiatan awal, guru datang ke kelas dan memberi salam kepada siswa yang ada di dalam kelas. Selanjutnya guru menyampaikan tujuan yang akan dicapai dan memberikan penjelasan tentang materi yang akan dipelajari. Kemudian guru menjelaskan kembali tahap strategi pembelajaran peningkatan kemampuan berpikir. (Tahap Orientasi)

Pada kegiatan inti tahap pertama, guru menanyakan mengenai materi sebelumnya dan mengkaitkan dengan materi yang akan dipelajari hari ini. Kemudian guru bertanya apa yang dimaksud dengan kelipatan persekutuan terkecil (KPK), sebagian besar siswa terdiam dan menunjukkan wajah ketidak tahuan mereka mengenai KPK. Namun ada beberapa siswa menjawab dengan membaca buku ringkasan mengenai materi KPK yang telah ditugaskan guru sebagai PR. Sampoerna menyebutkan "KPK adalah komisi pemberantasan korupsi umi", semua siswa di kelas tertawa dan guru segera menenangkan suasana. Guru mengkonfirmasi bahwa yang dimaksud KPK bukanlah komisi pemberantasan korupsi. (Tahap Pelacakan)

Pada tahap selanjutnya, guru bermain tepuk tangan gembira kembali. Permainan dilanjutkan dengan membagi siswa dalam 2 kelompok, kemudian masing-masing kelompok diberikan kelipatan yang berbeda. Kelompok A diberikan kelipatan 2 dan kelompok B diberikan kelipatan 3. Selanjutnya guru menyebutkan bilangan 8 sontak kelompok A bertepuk tangan, kemudian guru menyebutkan bilangan 9 sontak kelompok B bertepuk tangan, lalu guru menyebutkan bilangan 612 dan 18 secara berurutan sontak kelompok A dan B bertepuk tangan secara bersamaan. Guru bertanya mengapa kelompok A dan B bertepuk tangan secara bersama ketika guru menyebutkan bilangan 612 dan 18. Siswa menyebutkan "karena bilangan tersebut merupakan bilangan yang sama dari kelipatan 2 dan 3 umi”. (Tahap Konfrontasi)

Pada tahap selanjutnya guru bertanya apa yang dimaksud dengan kelipatan bilangan. Dari permainan tepuk tangan gembira siswa dapat mengetahui apa yang dimaksud dengan kelipatan. siswa menyebutkan "kelipatan adalah hasil perkalian bilangan tersebut dengan bilangan asli (1 234 dan seterusnya)". Selanjutnya guru bertanya kembali apa yang dimaksud dengan kelipatan persekutuan dua bilangan. Seluruh siswa menjawab "hasil perkalian dua bilangan yang sama umi". Kemudian guru bertanya berapa kelipatan persekutuan dari bilangan 2 dan 3. Siswa menyebutkan "6 12 dan 18 umi". Lalu guru bartanya lagi dari bilangan tersebut manakah bilangan yang terkecil. Siswa menyebutkan "bilangan 6 umi". Kemudian guru mengatakan bahwa 6 merupakan kelipatan persekutuan terkecil KPK. Selanjutnya guru meminta siswa untuk menyimpulkan apa yang dimaksud El-Ibtidaiy: Journal of Primary Education, Vol. 3, No. 2, Oktober 2020, Hal 168-197 
dengan kelipatan persekutuan terkecil KPK. Sebagian besar siswa dapat membuat kesimpulan dengan kalimat yang berbeda namun memiliki makna yang sama. Guru mengkonfirmasi jawaban siswa agar tidak terjadi kesalahan dalam mengartikan konsep KPK. Selanjutnya guru bersama siswa membuat kesimpulan mengenai KPK. (Tahap Inkuiri dan Tahap Akomodasi)

Pada tahap kegiatan penutup guru membagikan lembar kerja siswa atau soal tes pemecahan masalah yang akan dikerjakan siswa secara individu. Selama siswa melakukan kegiatan, guru memberikan bimbingan dan arahan kepada siswa yang mendapat kesulitan dalam memecahkan masalah. Setelah selesai dikerjakan, guru mengumpulkan masingmasing jawaban siswa dan memberikan hadiah kue kepada siswa yang mengerjakan dengan cepat. Kemudian guru berama siswa menyimpulkan pelajaran. Selanjutnya guru memberikan pekerjaan rumah (PR) kepada siswa dengan minta siswa untuk meringkas dan membaca materi mengenai materi selanjutnya. (Tahap Transfer)

Observasi yang telah dilakukan dalam penelitian ini dipusatkan pada proses maupun hasil tindakan pembelajaran yang diamati dalam aktivitas guru dan aktivitas siswa selama proses belajar mengajar berlangsung. Hasil observasi aktivitas guru siklus II dapat diketahui bahwa persentase pencapaian aktivitas guru dalam menggunakan strategi pembelajaran peningkatan kemampua berifikir SPPKB pada pertemuan ketiga Siklus II adalah $86 \%$ atau tergolong "Sangat Tinggi". Pada awal pertemuan aktivitas guru tergolong baik, karena aktivitas guru pada pertemuan kali ini sudah di dominasi skor 4 dan 5 "baik" dan "sangat baik". Namun ada beberapa kekurangan seperti guru hanya memberikan kepada beberapa siswa untuk mengemukakan hasil kesimpulan dari pemecahan masalah. Pada pertemuan keempat pencapaian skor aktivitas guru dalam menggunakan strategi pembelajaran peningkatan kemampuan berpikir adalah 32 dengan persentase 91\% tergolong dalam kategori "Sangat Tinggi". Pada pertemuan keempat aktivitas guru tergolong sangat tinggi dan sudah mengalami peningkatan dibandingkan pertemuan sebelumnya, karena aktivitas guru pada pertemuan kali ini sudah semua aspek mencapai skor 4 bahkan ada aspek yang mencapai skor 5.Berdasarkan hasil observasi terhadap aktivitas guru yang telah di lakukan, pelaksanaan penerapan SPPKB telah di lakukan oleh guru dengan baik dan sesuai dengan langkah-langkah yang telah di susun dalam RPP siklus II pertemuan keempat. Pada pertemuan keempat siklus II berada dalam kategori "Sangat Tinggi”, telah meningkat dari pertemuan sebelumnya dengan rentang persen $81 \%-100 \%$.

Menjelaskan tujuan dan melanjutkan materi telah mengalami peningkatan dibandingkan pada pertemuan sebelumnya, dalam hal ini guru mendapatkan skor 5 (sangat baik) karena dalam pelaksanaan guru sangat jelas dan lengkap dalam menyampaikan tujuan pembelajaran. Selain itu dalam mengkaitkan matateri sebelumnya dengan materi yang akan dipelajari, hal ini guru telah tepat dalam mengkaitkannya. Pada poin 2 guru mengalami peningkatan dari pertemuan sebelumnya, dalam hal ini guru mendapatkan skor 5 (sangat baik) karena dalam pelaksanaannya guru telah menguasai strategi ini dengan sangat baik. Sedangkan pada poin 3 guru mendapatkan skor 4 (baik) karena guru telah memberikan pertanyaan untuk mengetahui pemahaman kemampuan dasar siswa, hanya saja masih ada siswa yang tidak mendapat pertanyaan. 
Pada poin 4 dan 5 guru mendapatkan skor 4 (baik) karena dalam pelaksanaannya ada beberapa pertanyaan yang guru ajukan kurang mengarah pada pemecahan masalah dan kurang memberikan kesempatan siswa dalam memecahakan masalah. Sedangkan pada poin 6 guru mendapatkan skor 3 (cukup baik) karena dalam pelaksanaannya guru telah cukup baik dalam memberi kesempatan kepada siswa untuk mengemukakan hasil kesimpulan dari pemecahan masalah walaupun tidak seluruh siswa mendapatkan kesempatan mengemukakan hasil kesimpulan dari pemecahan masalah. Sedangkan pada poin 7 guru mendapatkan skor 5 (sangat baik) karena dalam pelaksanaannya guru sudah sangat baik dalam memberikan tugas sesuai materi yang dipelajari sebagai evaluasi untuk mengetahui kemampuan pemecahan masalah siswa.

\section{Tabel 9. Hasil Observasi Aktivitas Guru}

Pada Siklus II (Pertemuan 3 dan 4)

\begin{tabular}{|c|c|c|c|c|}
\hline No & Aktivitas Guru & $\begin{array}{c}\text { Skor } \\
\text { pert. } 3\end{array}$ & $\begin{array}{c}\text { Skor } \\
\text { pert. } 4\end{array}$ & $\begin{array}{c}\text { Total } \\
\text { Skor } \\
\text { Siklus } \\
\text { II }\end{array}$ \\
\hline 1. & $\begin{array}{l}\text { Guru menjelaskan tujuan yang akan dicapai dan } \\
\text { melanjutkan materi pada pertemuan yang sebelumnya. }\end{array}$ & 5 & 5 & 10 \\
\hline 2. & $\begin{array}{l}\text { Guru menjelaskan proses pembelajaran yang harus } \\
\text { dilakukan dalam setiap tahapan proses pembelajaran. }\end{array}$ & 5 & 5 & 10 \\
\hline 3. & $\begin{array}{l}\text { Guru melakukan tahap pelacakan dengan memberikan } \\
\text { pertanyaan untuk pemahaman kemampuan dasar siswa. }\end{array}$ & 4 & 4 & 8 \\
\hline 4. & $\begin{array}{l}\text { Guru melakukan tahap konfrontasi dengan memberikan } \\
\text { pertanyaan yang sampai akhirnya pada pemecahan } \\
\text { masalah. }\end{array}$ & 4 & 5 & 9 \\
\hline 5. & $\begin{array}{l}\text { Guru melakukan tahap Inkuiri dengan memberikan } \\
\text { kesempatan kepada siswa untuk memecahkan masalah. }\end{array}$ & 4 & 4 & 8 \\
\hline 6. & $\begin{array}{l}\text { Guru melakukan tahap Akomodasi dengan memberikan } \\
\text { kesempatan kepada siswa mengemukakan hasil kesimpulan dari } \\
\text { pemecahan masalah. }\end{array}$ & 3 & 4 & 7 \\
\hline 7. & $\begin{array}{l}\text { Guru melakukan tahap transfer dengan memberikan tugas } \\
\text { sesuai pembahasan dan sekaligus evaluasi. }\end{array}$ & 5 & 5 & 10 \\
\hline & $\begin{array}{c}\text { Total } \\
\text { Persentase }\end{array}$ & $\begin{array}{c}30 \\
86 \%\end{array}$ & $\begin{array}{c}32 \\
91 \%\end{array}$ & $\begin{array}{c}62 \\
89 \%\end{array}$ \\
\hline
\end{tabular}

Aktivitas siswa siklus II pertemuan ketiga dengan persentase tertinggi yaitu 100\%, terjadi ketika siswa mengerjakan tugas dari guru tentang materi yang telah diajarkan sebagai evaluasi. Walaupun siswa masih kebingungan dalam menjawab soal pemecahan masalah yang telah diberikan oleh guru. Persentase paling rendah dengan total $65 \%$, terjadi saat siswa siswa menjawab pertanyaan guru sesuai kemampuan dasarnya. Ini terjadi karena sebagian besar siswa kesulitan dalam menjawab pertanyaan guru dan beberapa siswa menjawab pertanyaan yang diberikan dengan bahasa buku karena siswa tersebut membaca buku yang terdapat diatas mejanya. Sehingga persentase pada aktivitas ini tergolong rendah dibandingkan aktivitas siswa yang lainnya. 
Berdasarkan tabel 10, persentase aktivitas belajar siswa pada mata pelajaran Matematika pada siklus II pertemuan keempat adalah 88\% atau tergolong "Sangat Tinggi". Aktivitas siswa pada pertemuan keempat sudah banyak peningkatan karena hampir semua aktivitas yang diamati didominasi persentase 81\%-100\% atau tergolong "Sangat Tinggi". Sedangkan aktivitas siswa dengan persentase tertinggi yaitu 100\% atau tergolong "Sangat Tinggi", terjadi ketika siswa mengerjakan tugas dari guru tentang materi yang telah diajarkan sebagai evaluasi. Dengan hasil ini dapat disimpulkan secara keseluruhan aktivitas siswa telah telaksana dengan baik.

Tabel 10, rata-rata persentase yang diperoleh aktivitas siswa pada pertemua 3 dan pertemuan 4 di siklus II yaitu 81\% dan terkategori "Sangat Tinggi". Perbaikan pada aktivitas siswa menjawab pertanyaan guru sesuai kemampuan dasar total rata-rata persentase sebesar $85 \%$. Hasil ini dapat disimpulkan secara keseluruhan aktivitas siswa telah terlaksana dengan sangat baik.

\section{Tabel 10. Hasil Observasi Aktivitas Siswa}

Pada Siklus II (Pertemuan 3 dan 4)

\begin{tabular}{|c|c|c|c|c|c|c|c|}
\hline \multirow{2}{*}{ No } & \multirow{2}{*}{ Aktivitas yang diamati } & \multicolumn{2}{|c|}{ Skor Pert. 3} & \multicolumn{2}{|c|}{ Skor Pert. 4} & \multicolumn{2}{|c|}{ Total Rata-rata } \\
\hline & & Jumlah & $\%$ & Jumlah & $\%$ & Jumlah & $\%$ \\
\hline 1 & $\begin{array}{l}\text { Siswa mendengarkan penjelasan } \\
\text { guru tentang tujuan pembelajaran } \\
\text { yang akan dicapai. }\end{array}$ & 15 & $75 \%$ & 17 & $85 \%$ & 16 & $80 \%$ \\
\hline 2 & $\begin{array}{l}\text { Siswa memperhatikan penjelasan } \\
\text { guru tentang proses pembelajaran } \\
\text { yang harus dilakukan dalam } \\
\text { setiap tahapan } \\
\text { pembelajaran. }\end{array}$ & 15 & $75 \%$ & 18 & $90 \%$ & 16,5 & $83 \%$ \\
\hline 3 & $\begin{array}{l}\text { Siswa menjawab pertanyaan guru } \\
\text { sesuai kemampuan dasarnya. }\end{array}$ & 13 & $65 \%$ & 17 & $85 \%$ & 15 & $75 \%$ \\
\hline 4 & $\begin{array}{l}\text { Siswa menjawab pertanyaan- } \\
\text { pertanyaan guru yang akhirnya } \\
\text { sampaipada pemecahan masalah. }\end{array}$ & 14 & $70 \%$ & 17 & $85 \%$ & 15,5 & $78 \%$ \\
\hline 5 & $\begin{array}{l}\text { Siswa terlibat dalam pemecahan } \\
\text { masalah matematika. }\end{array}$ & 14 & $70 \%$ & 17 & $85 \%$ & 15,5 & $78 \%$ \\
\hline 6 & $\begin{array}{l}\text { Siswa dapat mengemukakan hasil } \\
\text { kesimpulan dari masalah yang } \\
\text { timbul. }\end{array}$ & 14 & $70 \%$ & 17 & $85 \%$ & 15,5 & $78 \%$ \\
\hline 7 & $\begin{array}{l}\text { Siswa mengerjakan tugas dari } \\
\text { guru tentang materi yang telah } \\
\text { diajarkan sebagai evaluasi. }\end{array}$ & 20 & $100 \%$ & 20 & $100 \%$ & 20 & $100 \%$ \\
\hline & Jumlah & 105 & $75 \%$ & 123 & $88 \%$ & 81 & \\
\hline & Kategori & Tin & & Sangat & inggi & Sangat & inggi \\
\hline
\end{tabular}




\section{Kemampuan Pemecahan Masalah}

Tabel 11. Kemampuan Pemecahan Masalah

Siswa Siklus II

\begin{tabular}{lccc}
\hline \multicolumn{1}{c}{ Sub Aspek } & Jumlah Skor & Persentase & Kategori \\
\hline Pemahaman masalah & 58 & $96 \%$ & Sangat Baik \\
Perencanaan penyelesaian & 88 & $98 \%$ & Sangat Baik \\
Pelaksanaan perhitungan & 75 & $83 \%$ & Sangat Baik \\
$\begin{array}{l}\text { Pemeriksaan kembali hasil } \\
\text { perhitungan }\end{array}$ & 56 & $93 \%$ & Sangat Baik \\
\hline Jumlah & 276 & & \\
Rata-rata & 68,875 & $92,2 \%$ & Sangat Baik \\
\hline
\end{tabular}

Pada tabel 11 terlihat bahwa nilai aspek kemampuan pemecahan masalah Matematika siswa menggunakan strategi pembelajaran peningkatan kemampuan berpikir pada siklus II sudah mengalami peningkatan pada setiap subaspek. Persentase pada setiap aspek hampir mencapai persentase yang diharapkan yaitu $\mathrm{M}_{1}=90 \% \mathrm{M}_{2}=90 \%, \mathrm{M}_{3}=80 \%$ dan $\mathrm{M}_{4}=80 \%$, sedangkan kemampuan pemecahan masalah siswa pada setiap aspeknya yaitu $\mathrm{M}_{1}=96 \%$ $\mathrm{M}_{2}=98 \%, \mathrm{M}_{3}=83 \%$ dan $\mathrm{M}_{4}=93 \%$. Hal ini terjadi karena kemampuan pemecahan masalah siswa telah mengalami peningkatan setelah menerapkan strategi pembelajaran peningkatan kemampuan berpikir.

Tabel 12. Hasil Tes Kemampuan Pemecahan Masalah

Matematika Siswa Siklus II

\begin{tabular}{ccccc}
\hline No & \multicolumn{1}{c}{ Nilai } & \multicolumn{2}{c}{ Siklus I } & Keterangan \\
& & \multicolumn{1}{c}{ F } & $\%$ & \\
\hline 1 & $\square 70$ & 100 & $100 \%$ & Baik \\
2 & $<70$ & 0 & $0 \%$ & Cukup/Kurang \\
\hline
\end{tabular}

Berdasarkan tabel 12 diketahui rata-rata persentase ketuntasan klasikal yang diperoleh dari hasil kemampuan pemecahan masalah siswa pada siklus II (tes siklus) yang diambil dari tes kemampuan pemecahan masalah siswa dengan strategi pembelajaran peningkatan kemampuan berfikri SPPKB diketahui bahwa dari 20 orang siswa seluruh siswa mencapai nilai kemampuan pemecahan masalah yang sangat baik dengan persentase klasikal 100\% siswa yang memperoleh kualifikasi kemampuan pemecahan masalah kategori baik. Sehingga penelitian yang peneliti lakukan dengan strategi pembelajaran peningkatan kemampuan berfikri SPPKB untuk meningkatkan kemampuan pemecahan masalah siswa sudah dapat dikatakan berhasil.

\section{Refleksi}


Hasil kemampuan pemecahan masalah siswa pada siklus II dapat meningkat dibandingkan dari hasil kemampuan pemecahan masalah siswa pada siklus I, dengan demikian tindakan yang diberikan oleh guru pada siklus II berdampak lebih baik dari tindakan pada siklus I melalui strategi pembelajaran peningkatan kemampuan berfikri SPPKB.

\section{Pembahasan Aktivitas Guru}

Diketahui bahwa pada siklus I (pertemuan pertama dan kedua) aktivitas guru tergolong "Cukup Tinggi" dengan persentase 50\% berada pada rentang 41-60\%. Pada siklus II (pertemuan ketiga dan keempat) meningkat menjadi 89\% tergolong "Sangat Tinggi", berada pada rentang 81- 100\% lebih jelas dapat dilihat pada tabel berikut ini:

\section{Tabe1 13. Rekapitulasi Aktivitas Guru}

\section{Siklus I dan Siklus II}

\begin{tabular}{|c|c|c|c|}
\hline No & Aktivitas Guru & Siklus I & Siklus II \\
\hline 1. & $\begin{array}{l}\text { Guru menjelaskan tujuan yang akan dicapai dan melanjutkan } \\
\text { materi pada pertemuan yang sebelumnya. }\end{array}$ & 5 & 10 \\
\hline 2. & $\begin{array}{l}\text { Guru menjelaskan proses pembelajaran yang harus dilakukan } \\
\text { dalam setiap tahapan proses pembelajaran. }\end{array}$ & 5 & 10 \\
\hline 3. & $\begin{array}{l}\text { Guru melakukan tahap pelacakan dengan memberikan } \\
\text { pertanyaan untuk pemahaman kemampuan dasar siswa. }\end{array}$ & 6 & 8 \\
\hline 4. & $\begin{array}{l}\text { Guru melakukan tahap konfrontasi dengan memberikan } \\
\text { pertanyaan yang sampai akhirnya pada pemecahan masalah. }\end{array}$ & 5 & 9 \\
\hline 5. & $\begin{array}{l}\text { Guru melakukan tahap Inkuiri dengan memberikan } \\
\text { kesempatan kepada siswa untuk memecahkan masalah. }\end{array}$ & 5 & 8 \\
\hline 6 & $\begin{array}{l}\text { Guru melakukan tahap Akomodasi dengan memberikan } \\
\text { kesempatan kepada siswa mengemukakan hasil kesimpulan } \\
\text { dari pemecahan masalah. }\end{array}$ & 4 & 7 \\
\hline 7. & $\begin{array}{l}\text { Guru melakukan tahap transfer dengan memberikan tugas } \\
\text { sesuai pembahasan dan sekaligus evaluasi. }\end{array}$ & 5 & 10 \\
\hline & $\begin{array}{c}\text { Total } \\
\text { Persentase }\end{array}$ & $\begin{array}{c}35 \\
50 \%\end{array}$ & $\begin{array}{c}62 \\
89 \%\end{array}$ \\
\hline
\end{tabular}

Perbandingan persentase aktivitas guru dengan penerapan strategi pembelajaran peningkatan kemampuan berpikir siklus I dan siklus II juga dapat dilihat pada histogram berikut: 


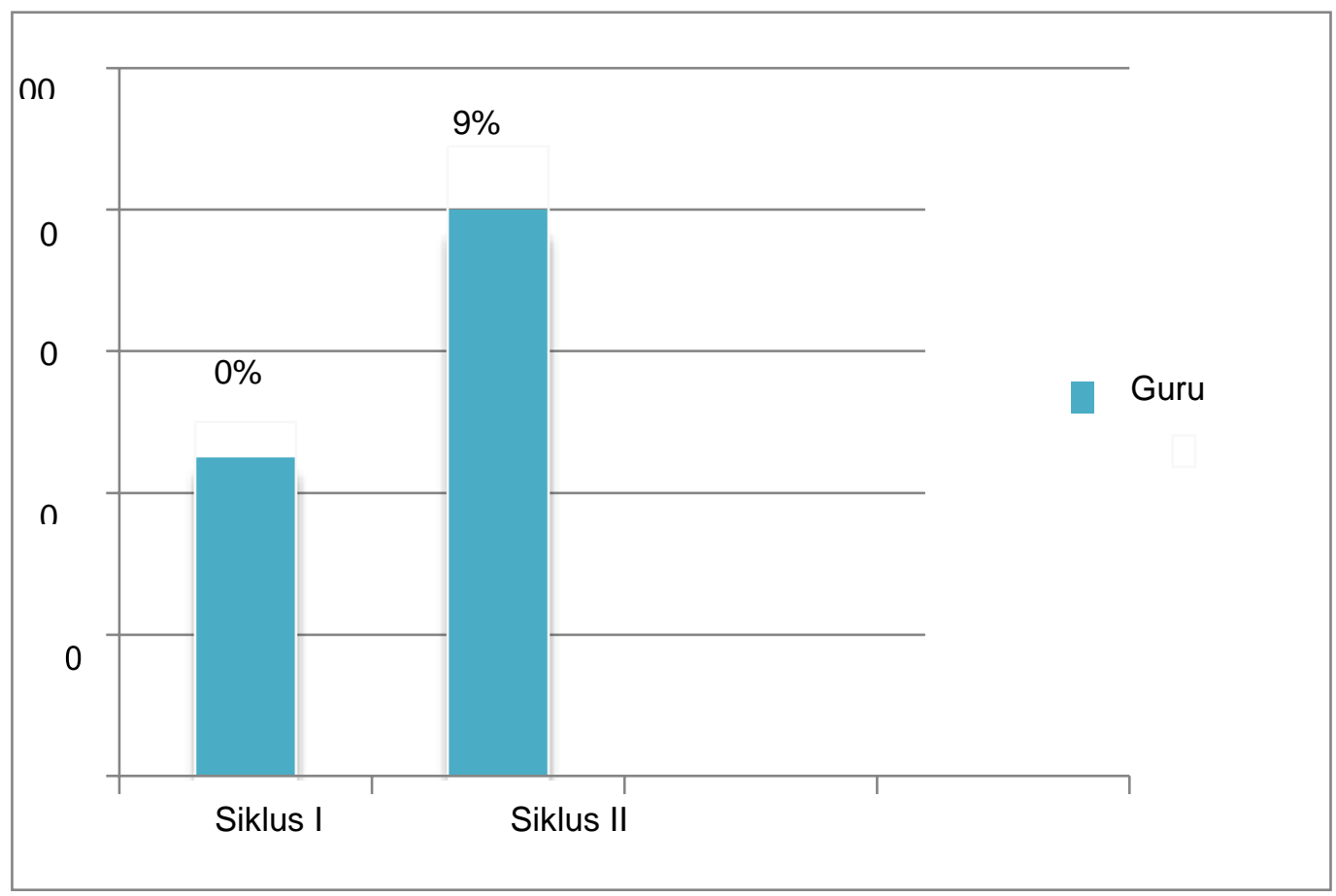

Gambar 2. Grafik Rekapitulasi Aktivitas Guru Siklus I dan Siklus II

\section{Aktivitas Siswa}

Rekapitulasi aktivitas siswa selama kegiatan belajar mengajar dengan menggunakan penerapan strategi pembelajaran peningkatan kemampuan berpikir pada siklus I (pertemuan pertama dan kedua) memperoleh persentase 56\% tergolong "Cukup Tinggi" berada pada rentang 41-60\%. Pada siklus II (pertemuan ketiga dan keempat) meningkat menjadi 81\% tergolong "Sangat Tinggi", berada pada rentang 81-100\% lebih jelas dapat dilihat pada tabel berikut ini:

\section{Tabel 14. Rekapitulasi Aktivitas Siswa}

\section{Siklus I dan Siklus II}

\begin{tabular}{|c|c|c|c|}
\hline No & Aktivitas Siswa & Siklus I & Siklus II \\
\hline 1. & $\begin{array}{l}\text { Siswa mendengarkan penjelasan guru tentang tujuan } \\
\text { pembelajaran yang akan dicapai. }\end{array}$ & 10 & 16 \\
\hline 2. & $\begin{array}{l}\text { Siswa memperhatikan penjelasan guru tentang proses } \\
\text { pembelajaran yang harus dilakukan dalam setiap tahapan } \\
\text { proses pembelajaran. }\end{array}$ & 12 & 17 \\
\hline 3. & $\begin{array}{l}\text { Siswa menjawab pertanyaan guru sesuai kemampuan } \\
\text { dasarnya. }\end{array}$ & 10 & 15 \\
\hline 4. & $\begin{array}{l}\text { Siswa menjawab pertanyaan-pertanyaan guru yang } \\
\text { akhirnya sampai pada pemecahan masalah. }\end{array}$ & 9 & 16 \\
\hline 5. & Siswa terlibat dalam pemecahan masalah matematika. & 10 & 16 \\
\hline
\end{tabular}


6. Siswa dapat mengemukakan hasil kesimpulan dari masalah yang timbul.

7. Siswa mengerjakan tugas dari guru tentang materi yang telah diajarkan sebagai evaluasi.

\begin{tabular}{rcc} 
telah diajarkan sebagai evaluasi. & 20 & 20 \\
\hline Total & $\mathbf{7 9}$ & $\mathbf{1 1 4}$ \\
Persentase & $\mathbf{5 6 \%}$ & $\mathbf{8 1} \%$ \\
\hline
\end{tabular}

Perbandingan persentase aktivitas guru dengan penerapan strategi pembelajaran peningkatan kemampuan berpikir siklus I dan siklus II juga dapat dilihat pada histogram berikut:

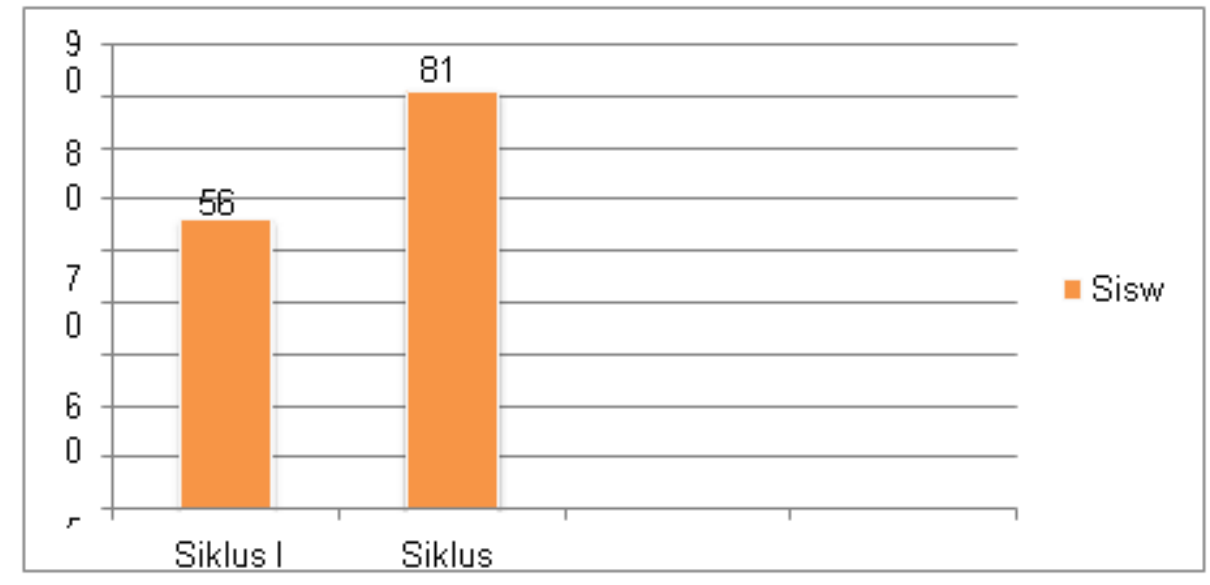

Gambar 3. Grafik Rekapitulasi Aktivitas Siswa Siklus I dan Siklus II

\section{Kemampuan Pemecahan Masalah}

Perbandingan kemampuan pemecahan masalah siswa dilihat dari sebelum tindakan, siklus I dan siklus II secara jelas dapat dilihat pada tabel berikut:

Tabel 15. Rekapitulasi Kemampuan Pemecahan Masalah Matematika Siswa Sebelum Tindakan, Siklus I, dan Siklus II

\begin{tabular}{lcccccc}
\hline \multicolumn{1}{c}{ Sub Aspek } & $\begin{array}{c}\text { Pra } \\
\text { tindakan }\end{array}$ & $\%$ & Siklus I & $\%$ & Siklus II & $\%$ \\
\hline Pemahaman masalah & 15,00 & $75 \%$ & 53 & $88 \%$ & 58 & $96 \%$ \\
Perencanaan penyelesaian & 17,00 & $57 \%$ & 77 & $86 \%$ & 88 & $98 \%$ \\
Pelaksanaan perhitungan & 17,00 & $57 \%$ & 57 & $63 \%$ & 75 & $83 \%$ \\
Pemeriksaan kembali hasil & 8,00 & $40 \%$ & 40 & $66 \%$ & 56 & $93 \%$ \\
Perhitungan & & & & & & \\
\hline Jumlah & 57,00 & & 226 & & 276 & \\
Rata-rata & 2,85 & $57 \%$ & 56,5 & $76 \%$ & 68,87 & $92,2 \%$ \\
\hline
\end{tabular}


Tabel 16. Rekapitulasi Hasil Tes Kemampuan Pemecahan Masalah Matematika Siswa Sebelum Tindakan, Siklus I, dan Siklus II

\begin{tabular}{ccccccccc}
\hline No & Nilai & \multicolumn{2}{c}{$\begin{array}{c}\text { Sebelum } \\
\text { Tindakan }\end{array}$} & \multicolumn{2}{c}{ Siklus I } & \multicolumn{2}{c}{ Siklus II } & Keterangan \\
& & F & $\%$ & F & $\%$ & F & $\%$ & \\
\hline 1 & $\square 70$ & 3 & $15 \%$ & 14 & $70 \%$ & 20 & $100 \%$ & Baik \\
2 & $<70$ & 17 & $85 \%$ & 6 & $30 \%$ & 0 & $0 \%$ & Cukup/Kurang \\
\hline
\end{tabular}

Setelah diadakan refleksi pada tindakan siklus I, hasil tes kemampuan pemecahan masalah siswa dengan strategi pembelajaran peningkatan kemampuan berpikir dapat meningkat pada siklus II dengan hasil tes kemampuan pemecahan masalah siswa yaitu 100\% memperoleh kualifikasi kemampuan pemecahan masalah siswa kategori baik. Angka ini berada pada rentang 86-100\% kategori sangat baik. Angka 100\% yang dicapai siswa secara keseluruhan sudah dapat dikatakan berhasil karena telah melewati indikator keberhasilan yang ditetapkan dalam penelitian ini yaitu 75\%. Artinya penelitian yang peneliti lakukan dengan strategi pembelajaran peningkatan kemampuan berpikir untuk meningkatkan kemampuan pemecahan masalah siswa sudah dapat dikatakan berhasil.

Perbandingan antara hasil kemampuan pemecahan masalah siswa pada sebelum tindakan, siklus I, dan siklus II secara jelas juga dapat dilihat pada grafik berikut:

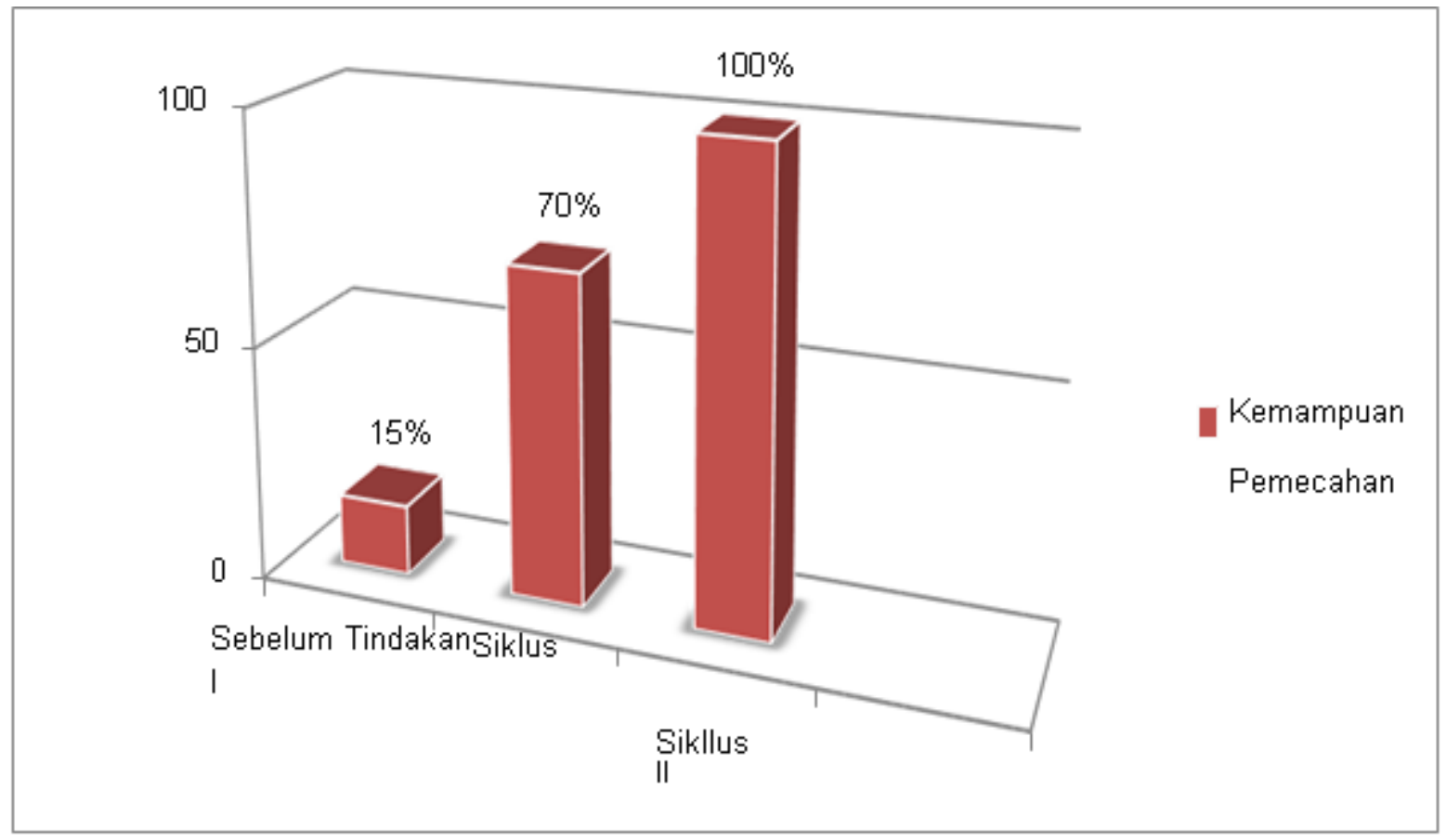

Gambar 4. Grafik Peningkatan Hasil Tes Kemampuan Pemecahan Masalah Matematika Siswa Sebelum Tindakan, Siklus I, dan Siklus II

Berdasarkan gambar 4 dapat diketahui bahwa hasil kemampuan pemevahan masalah siswa secara individual pada sebelum tindakan, siklus I, dan siklus II mengalami El-Ibtidaiy: Journal of Primary Education, Vol. 3, No. 2, Oktober 2020, Hal 168-197 
peningkatan. Secara keseuluran pada sebelum tindakan memperoleh hasil kemampuan pemecahan masalah siswa kualifikasi baik dengan persentase 15\% tergolong kategori kurang sekali, setelah ada perbaikan pada siklus I, hasil kemampuan pemecahan masalah siswa mengalami peningkatan dengan memperoleh persentase 70\% tergolong kategori cukup, namun belum mencapai indikator keberhasil kemampuan pemecahan masalah yang telah ditetapkan yaitu 75\% siswa memperoleh kualifikasi baik, setelah ada perbaikan pada siklus II, hasil kemampuan pemecahan masalah siswa pada siklus II meningkat dengan hasil kemampuan pemecahan masalah siswa yang memperoleh kualifikasi baik dengan persentase 100\% tergolong kategori sangat baik. Hal ini berarti nilai kemampuan pemecahan masalah siswa meningkat dari ketegori kurang sekali menjadi kategori sangat baik. Hal ini menunjukkan bahwa strategi pembelajaran peningkatan kemampuan berpikir cukup efektif untuk meningkatkan kemampuan pemecahan masalah siswa, walaupun secara individual kemampuan pemecahan masalah siswa belum semua mencapai kategori sangat baik.

Kemampuan pemecahan masalah sangat penting dalam pembelajaran matematika, dalam kemampuan tersebut siswa akan mempunyai kemampuan dasar yang bermakna lebih dari sekedar kemampuan berpikir. Strategi pembelajaran peningkatan kemampuan berpikir berhasil meningkatkan kemampuan pemecahan masalah siswa walaupun pada awalnya siswa agak kesulitan untuk mengikuti setiap kegiatan pembelajarannya. Namun dengan arahan dan bimbingan dari guru, maka siswa mulai belajar mengikuti tahapan strategi pembelajaran peningkatan kemampuan berpikir dengan baik. Dengan strategi ini materi pelajaran tidaklah disajikan begitu saja kepada siswa, akan tetapi siswa dibimbing untuk menemukan sendiri konsep yang harus dikuasai melalui proses dialogis yang terus menerus dengan memanfaatkan pengalaman siswa.

Menurut Sanjaya dalam bukunya, strategi pembelajaran peningkatan kemampuan berpikir merupakan model pembelajaran yang bertumpu kepada pengembangan kemampuan berpikir siswa melalui telaahan fakta-fakta atau pengalaman anak sebagai bahan untuk memecahkan masalah. Pembelajaran peningkatan kemampuan berpikir ini siswa dituntut untuk mampu berpikir untuk memecahkan masalah yang diajukan. Dengan demikian strategi pembelajaran peningkatan kemampuan berpikir efektif untuk meningkatkan kemampuan pemecahan masalah siswa.

\section{KESIMPULAN DAN SARAN}

\section{KESIMPULAN}

Berdasarkan hasil penelitian dan pembahasan, dapat disimpulankan bahwa penerapan strategi pembelajaran peningkatan kemampuan berpikir dapat meningkatkan kemampuan pemecahan masalah siswa pada pelajaran Matematika kelas IV Madrasah Ibtidaiyah Tualang. Adapun kemampuan pemecahan masalah siswa termasuk dalam kategori kurang sekali (15\%) pada sebelum tindakan kemudian meningkat menjadi kategori cukup $(70 \%)$ pada siklus I, begitu juga siklus II meningkat menjadi kategori sangat baik (100\%). Dari temuan diatas maka dapat di tarik sebuah kesimpulan bahwa 
kemampuan pemecahan masalah siswa menggunakan strategi pembelajaran peningkatan kemampuan berpikir sudah berhasil karena $\square 75 \%$ kemampuan pemecahan masalah siswa berada pada kualifikasi baik. Upaya yang guru lakukan dalam meningkatkan kemampuan pemecahan masalah siswa menggunakan strategi pembelajaran peningkatan kemampuan berpikir, diantaranya ialah: (1) Tahap Orientasi, menjelaskan tujuan yang akan dicapai dan menjelaskan proses pembelajaran yang harus dilakukan. (2) Tahap Pelacakan, memberi pertanyaan untuk mengetahui kemampuan dasar siswa sesuai dengan pokok persoalan. (3) Tahap Konfrontasi, memberikan pertanyaan pancingan sehingga siswa dapat memahami masalah. (4) Tahap Inkuiri, memberikan kesempatan kepada siswa untuk memecahkan masalah sehingga siswa dapat memikirkan strategi atau langkah apa yang digunakan dalam memecahkan masalah tersebut. (5) Tahap Akomodasi, memberikan kesempatan kepada siswa untuk mengemukakan hasil kesimpulan suatu masalah sehingga siswa dapat memeriksa kembali proses dan hasil dalam memecahkan masalah tersebut. (6) Tahap Transfer, memberikan siswa tugas berupa lembar kerja yang berisi soal pemecahan masalah sehingga dapat melatih kemampuan pemecahan masalah siswa.

Hasil observasi aktivitas guru menggunakan strategi pembelajaran peningkatan kemampuan berpikir SPPKB, pada siklus I memperoleh persentase 50\% dengan kategori cukup tinggi. Kemudian mengalami peningkatan pada siklus II dengan persentase $89 \%$ pada ketegori sangat tinggi. Sedangkan hasil observasi aktivitas siswa menggunakan strategi pembelajaran peningkatan kemampuan berpikir SPPKB, pada siklus I memperoleh persentase 56\% dengan kategori cukup tinggi. Kemudian mengalami peningkatan pada siklus II dengan persentase $81 \%$ pada ketegori sangat tinggi.

\section{SARAN}

Penerapan strategi pembelajaran peningkatan kemampuan berpikir sangat efektif dalam meningkatkan kemampuan pemecahan masalah siswa pada pelajaran Matematika, maka diharapkan guru dapat melakukan tahap orientasi, pelacakan, konfrontasi, inkuiri, akomodasi dan transfer dalam pembelajaran dengan baik. Penerapan strategi pembelajaran peningkatan kemampuan berpikir akan lebih bermakna apabila dipadukan dengan strategi lain yang mendukung sehingga dapat melibatkan semua siswa dalam proses pembelajaran. Dalam menerapkan strategi pembelajaran peningkatan kemampuan berpikir diharapkan kepada guru untuk dapat mengelola waktu seefektif mungkin, karena strategi ini banyak menyita waktu. Peneliti lain perlu melakukan penelitian lebih lanjut yang lebih mendalam mengenai strategi pembelajaran peningkatan kemampuan berpikir karena dalam penelitian peneliti menemukan bahwa SPPKB tidak hanya dapat meningkatkan kemampuan pemecahan masalah Matematika siswa namun banyak aspek yang lain yang bisa ditingkatkan. Untuk itu peneliti menawarkan kepada calon peneliti untuk meniliti aspek-aspek yang lain; misalnya kemampuan berpikir kritis, kemampuan pemahaman konsep dan keaktifan belajar. 


\section{REFERENSI}

Abuddin Nata. 2001. Perspektif Islam Tentang Strategi Pembelajaran. Jakarta: Kencana. Anas Sudjono. 2004. Pengantar Statistik Pendidikan. Jakarta: Raja Grafindo Persada.

Annisaul Khairat, "Penerapan Strategi Pembelajaran Peningkatan Kemampuan Berpikir Pada Mata Pelajaran Fiqih Materi Zakat Di Madrasah Tsnawiyah Negeri Batusangkar Kabupaten Tanah Datar”, (Batusangkar: IAIN Batusangkar, 2017),

Desi Anwar. 2002. Kamus Lengkap Berbahasa Indonesia. Surabaya: Amelia.

Deti Rostika dan Herni Junita, "Peningkatan Kemampuan Pemecahan Masalah Siswa SD Dalam Pembelajaran Matematika Dengan Model Diskursus Multy Reppresentation (DMR)", Jurnal Pendidikan Dasar Vol. 9. No. 1, 2017.

Djaali. 2014. Psikologi Pendidikan. Jakarta: Bumi Aksara.

Djamilah Bondan Widjajanti Kemampuan Pemecahan Masalah Matematis Mahasiswa Calon Guru Matematika: Apa Dan Bagaimana Mengembangkannya, Seminar Nasional Matematika dan Pendidikan Matematika, tersedia dalam: www.google.com/P25-Djamilah Bondan Widjajanti.pdf, didownload pada tanggal 25 Mei 2019.

Mardia Hayati. 2012. Desain Pembelajaran Berbasis Karakter. Pekanbaru: Al-Mujtahadah Press.

Melly Andriani \& Mimi Hariyani. 2013. Pembelajaran Matematika SD/MI. Pekanbaru: Benteng Media. Muhammad Yaumi. 2012. Pembelajaran Berbasis Multiple Intelligence. Jakarta: Dian Rakyat.

Nana Sudjana. 2017. Penilaian Proses Hasil Belajar Mengajar. Bandung: PT. Remaja Rosdakarya.

Ngalim Purwanto. 2017. Prinsip-prinsip dan Teknik Evaluasi Pengajaran. Bandung: PT. Remaja Rosdakarya.

Riduwan. 2015. Belajar Mudah Penelitian Untuk Guru-Karyawan dan Penelitian Pemula. Bandung: Alfabeta.

. 2010. Skala Pengukuran Variabel-variabel Penelitian. Bandung: Alfabeta. Sardiman A.M. 2016. Interaksi dan Motivasi Belajar Mengajar. Jakarta: Rajawali Pers.

Siti Mawaddah dan Hana Anisah, Kemampuan Pemecahan Masalah Matematis Siswa pada Pembelajaran Matematika dengan Menggunakan Model Pembelajaran Generatif di SMP, (Pendidikan Matematika FKIP Universitas Lambung Mangkurat), V.3(2).

Sudjimat, D.A., 1995. Pembelajaran Pemecahan Masalah: Tinjauan singkat Berdasarkan teori Kognitif.

Jurnal Pendidikan Matematika dan Sains. Malang: IKIP Malang.

Suharsimi Arikunto, dkk. 2019. Penelitian Tindakan Kelas. Jakarta: Bumi Aksara. 
Wina Sanjaya. 2016. Strategi Pembelajaran Berorientasi Standar Proses Pendidikan. Jakarta: Kecana.

Zaenal Arifin, Meningkatkan Hasil Belajar dengan Strategi Pembelajaran Peningkatan Kemampuan Berfikir, Jurnal Theorems Vol. 2 No. 2, Januari 2018.

Zulfah, Pengaruh Penerapan Model Pembelajaran Kooperatif Tipe Think Pair Share Dengan Pendekatan Heuristik Terhadap Kemampuan Pemecaham Masalah Metematis Siswa MTs Negeri Naumbai Kecamatan Kampar, Jurnal Cendekia Vol. 01 No. 2, November. 